\title{
Takım Kolektivizminin Performans ve Vatandaşlık Davranışına Etkisi: Takım Arkadaşı İşlem Adaletinin Aracılık Rolü
}

\author{
Arzu Sert Özen
}

Gebze Teknik Üniversitesi

\author{
Meral Elçi
}

Gebze Teknik Üniversitesi

\begin{abstract}
Özet
Bu çalışmanın amacı, takım kolektivizmi inancının, takım vatandaşlık davranışı ile takım görev performansı üzerindeki etkisini test etmek ve bu ilişkide takım arkadaşı işlem adaletinin aracı rolünün bulunup bulunmadiğını incelemektir. Bu araştırma, İstanbul, İzmir, Kocaeli ve Mersin illerinde faaliyet gösteren işletmelerin üretim ve hizmet takımlarında görev alan 560 kişi $(\mathrm{N}=93$ takım) üzerinde kısmi en küçük kareler yapısal eşitlik modellemesi (PLSYEM) kullanılarak yapılmıştır. Kuram düzeyi takım olduğundan dolayı araştırmaya dâhil olan bütün yapılar takım düzeyinde kavramsallaştırılmıştır. Elde edilen bulgular, takım kolektivizmi inancının hem takım arkadaşı işlem adaleti hem de takım görev performansı ile takım vatandaşlık davranışı üzerinde anlamlı etkiye sahip olduğunu göstermektedir. Buna ek olarak, takım kolektivizmi inancı ile takım görev performansı ve takım vatandaşlık davranışı arasındaki ilişkide takım arkadaşı işlem adaletinin kısmi aracılık etkisi olduğu bulunmuştur.
\end{abstract}

Anahtar kelimeler: Takım kolektivizmi inancı, takım arkadaşı işlem adaleti, takım görev performansı, takım vatandaşlık davranışı

\begin{abstract}
The purpose of this cross-sectional study was to test the effects of team collectivism on team citizenship behavior and team task performance and examine whether peer procedural justice had a mediating role in the relationships of team collectivism with team citizenship behavior and team task performance. The research design was based on survey data collected from 560 employees in 93 production and service teams from companies located in Istanbul, Izmir, Kocaeli, and Mersin provinces in Turkey. The hypotheses in the model were tested using partial least squares structural equation modeling (PLS-SEM). Since the theoretical level is team, all the structures involved in the research were conceptualized at the team level. The results showed that team collectivism was positively related to peer procedural justice, team citizenship behavior, and team task performance. Additionally, it was found that peer procedural justice had a partial mediating role in the relationships of team collectivism with team citizenship behavior and team task performance.
\end{abstract}

Keywords: Team collectivism belief, peer procedural justice, team task performance, team citizenship behavior

Yazar Notu: Bu çalışma ilk yazarın ikinci yazar danışmanlığında hazırladığı doktora tezinin bir kısmından üretilmiştir. Yazışma Adresi: Doktora Öğr. Arzu Sert Özen, Gebze Teknik Üniversitesi, İşletme Fakültesi, 41400, Gebze/Kocaeli.

E-posta: arzusertt@gmail.com

Gönderim Tarihi: 27.04 .2018

Kabul Tarihi: 02.04.2019 
"Hizlı gitmek istiyorsan yalnız git, ama ĕger uzağa gitmek istiyorsan birlikte git”, -Afrika Atasözü.

Takımlar ortak bir amacı gerçekleştirmek için karŞ11klı olarak etkileşimde bulunan iki veya daha fazla kişiden oluşan birimlerdir (Baker ve Salas, 1997). Bu birimler örgütsel performans üzerindeki olumlu etkilerinden dolayı günümüzdeki örgütlerde oldukça rağbet kazanmışlardır. Ancak takım uygulamaları kolay bir konu değildir ve yüksek performans elde edebilmek için örgütlerin takım esaslı stratejiler geliştirmesi gerekmektedir (Gundlach, Zivnuska ve Stoner, 2006). Takımın amaçlarını veya görevlerini yerine getirme derecesini ifade eden takım performansı (Bell, 2007), takımın başarısını ortaya koyan en önemli göstergedir. Takımın başarılı bir performans gösterebilmesi için takım üyelerinin kendilerine verilen görevleri bilişsel, sözel ve davranışsal faaliyetlerle iş birliği yaparak yerine getirmeleri gerekmektedir (Marks, Mathieu ve Zaccaro, 2001). Takım bağlamında kişilerin birbirleriyle iş birliği yapmalarında etkili olan unsurlardan biri toplulukçuluktur (Wagner, 1995). Araştırmalar göstermektedir ki bireycilik ve toplulukçuluk eğilimlerine dikkat edilmeden takımlara yerleştirilen kişiler sebebiyle örgütler takımlardan yeterince istifade edememektedirler. Bireycilik eğilimleri daha yüksek olan kişiler tek başlarına çalıştıklarında başarılı olurken, toplulukçuluk eğilimleri yüksek olan bireyler takım çalışmalarında daha başarılı olmaktadırlar (Van Dyne, Vandewalle, Kostova, Latham ve Cummings, 2000). Toplulukçuluk eğilimi yüksek olan bireyler takım çalışması içerisinde öncelikli olarak performansa odaklandıklarından dolayı tek başına çalıştıkları işlere göre daha fazla çaba göstermektedirler (Earley, 1989). Ayrıca kişi ile örgüt, takım ve yöneticiler gibi çalışma ortamındaki farklı taraflar arasındaki etkileşimin önem teşkil etmesi nedeniyle, kişi ile çalıştığı ortam arasındaki uyumun çalışan davranışları üzerinde olumlu etkilere sahip olduğu görülmektedir (Molina, Jakopec, Cropanzano ve Moliner, 2017).

Geleneksel olarak toplulukçuluk, kültürel düzeyde bir yap1 olarak incelenirken (Triandis, 1989; Triandis, Leung, Villareal ve Clack, 1985), bazı araştırmacılar tarafından kültürel düzeyden ziyade aynı kültür içinde bulunan bireyler arasındaki psikolojik farklılıklar olarak incelenmiştir (örn., Earley, 1989; Earley, 1993; Earley, 1994; Eby ve Dobbins, 1997; Erez ve Somech, 1996; Kirkman ve Shapiro, 2001; Moorman ve Blakely, 1995; Wagner, 1995; Wagner, Humphrey, Meyer ve Hollenbeck, 2012; Wagner ve Moch, 1986). Yapılan çalışmalarda psikolojik toplulukçuluğun takım-üye davranışı üzerinde etkilerinin olduğu ortaya konulmuş olsa da toplulukçuluğu takım yapısındaki bir değişken olarak inceleyen az sayıda çalışma (örn., Bell, 2007; Colquitt, Noe ve Jackson, 2002; Dayan ve Çolak, 2008) mevcuttur.

Takım üyeleri birbirlerinden bağımsız kişiler değildirler. Birbirleriyle karşılıklı bir ilişki içerisinde bulunduklarından ve aynı ortamı paylaştıklarından dolayı takım içerisindeki kişiler birbirlerini etkilemektedirler (Kenny ve La Voie, 1985). "Yeryüzünde insanın en büyük ilgisi adalettir"'-Daniel Webster (Mello, 2015). Düşünürün de dediği gibi adalet insanların en büyük ilgisiyse, birbirleri ile olan etkileşimlerinde de en çok önem verdikleri konuların başında gelecektir. $\mathrm{Bu}$ bağlamda araştırmaya konu olan takım arkadaşı adaleti kavramı, takım çalışmaları üzerine odaklanan sosyal psikoloji ile ilgili alanyazından elde edilmiştir. Geleneksel anlamda örgütsel adalet, işyerindeki sosyal etkileşimin kalitesi olarak tanımlanan bir kavramdır ve çalıșanlara işyerlerinde örgütsel otorite tarafından ne ölçüde adaletli davranıldığını ifade etmektedir (Elovainio ve ark., 2005). Bu kavram çerçevesinde çalışanların adaletle ilgili bireysel tecrübeleri değerlendirilmektedir. Örgütsel adalet iklimi kavramı ise çalışanların kendilerine ne ölçüde adil davranıldığına dair ortak algılarını ifade etmektedir ve bu nedenle takım düzeyinde değerlendirilmektedir. Takım arkadaşı adaleti ise kavramsal olarak örgütsel adalet ikliminden farklı bir yapıdır ve aynı takım içerisinde birlikte çalışan ve birbirleri üzerinde resmi bir otoriteye sahip olmayan takım üyelerinin birbirlerine karşı olan davranışlarına dair ortak adalet algılarını ifade etmektedir. Örgütsel adalet ikliminin kaynağı örgütsel otoriteyken, takım arkadaşı adaletinde adaletin kaynağı çalışma arkadaşlarıdır (Cropanzano, Li ve Benson, 2011). Molina ve arkadaşlarına (2017) göre takım arkadaşı adaleti ile ilgili çalışmalar, örgütsel adalet ikliminin ötesinde çalışan tepkilerini de açıklayarak işyeri adaleti araştırmalarına ek bir değer katmaktadır.

Takım arkadaşı adaleti ile ilgili ilk görgül çalışma Cropanzano ve arkadaşları (2011) tarafından yapılmıştır. Gerçekleştirilen az sayıda çalışmada (Cropanzano ve ark., 2011; Jakopec, Susanj ve Molina, 2015; Li, Cropanzano ve Bagger, 2013; Molina, Moliner, Martinez-Tur, Cropanzano ve Peiro, 2015) takım arkadaş1 adaleti araştırılmış olsa da araştırma sonuçları takım arkadaşı adaletinin takım davranışı üzerinde olumlu etkilerinin olduğunu göstermektedir. Cropanzano ve arkadaşları (2011) üniversite öğrencilerinden oluşan 170 takım üzerinde yaptıkları çalışmada, takım arkadaşı işlem adaleti ve kişilerarası takım arkadaşı adaletinin görev takım çalışması süreci aracılığıyla görev performansı üzerinde ve kişilerarası takım çalışması süreci aracılığıyla takım vatandaşlık davranışı üzerinde olumlu etkilerinin olduğunu bulmuşlardır. Jakopec ve arkadaşlarına (2015) göre takım arkadaşı adaletinin örgütsel adalet iklimine kıyasla takım birliği üzerinde nispeten daha güçlü ve olumlu 
yönde bir etkisi vardır. Li ve arkadaşları (2013) dönem boyunca takım projesinde görev alan üniversite öğrencilerinden oluşan örneklem üzerinde yaptıkları çalışmada, takım arkadaşı adaleti ve adalet ikliminin takım memnuniyeti, iş birlikçi takım çalışması süreci ve takım performansına etkisini incelemişlerdir. Araştırmanın bulguları, takım arkadaşı adaleti ikliminin iş birlikçi takım çalışması süreci ile ilişkili olduğunu, buna karşın adalet ikliminin ise anlamlı bir ilişkisinin bulunmadığını ortaya koymuştur. Ayrıca her iki iklim türünün de iş birlikçi takım çalışması süreci aracılığı ile takım memnuniyeti ve takım performansı üzerinde istatistiksel olarak anlamlı etkisinin olmadığı bulunmuştur. Molina ve arkadaşları (2015) sağl1k sektöründe adalet-kalite ilişkisi üzerine yapmış oldukları çalışmada, takım arkadaşı adaletinin ilişkisel hizmet kalitesini etkilediğini, adalet ikliminin ise işlevsel hizmet kalitesini etkilediğini bulmuşlardır.

İşlem adaleti; iş tatmini, vatandaşlık davranışı ve performans gibi önemli örgütsel sonuçlarla bağlantılı olduğu meta-analizlerle kanıtlanmış olan (örn., Colquitt, Conlon, Wesson, Porter ve Ng, 2001) bir kavramdır. Ayrıca, grup-değer modeline göre (Tyler, Degoey ve Smith, 1996) işlem adaleti, bireylerin bağlı oldukları gruplar ile olan sosyal bağlantıları hakkında daha fazla bilgi verdiği ve davranışlarını etkilediği için diğer adalet türlerine göre daha fazla öne çıkmaktadır (Tyler ve Blader, 2003; Walumbwa, Wu ve Orwa, 2008). Bu nedenle işlem adaleti, adalet iklimine dair alanyazın araştırmacıları tarafindan en çok ilgi gören adalet boyutudur (örn., Colquitt ve ark., 2002; Dietz, Robinson, Folger, Baron ve Schulz, 2003; Ehrhart, 2004; Emuwa, 2013; Henttonen, Janhonen ve Johanson, 2013; Mossholder, Bennet ve Martin, 1998; Naumann ve Bennett, 2000,2002; Sung, Choi ve Kang, 2017; Tse, Lam, Gu ve Lin, 2018). Bireysel düzeyde (örn., Moorman ve Blakey, 1995; Moorman, Niehoff ve Organ, 1993) ve takım düzeyinde (örn., Cole, Carter ve Zhang, 2013; Ehrhart, 2004; Naumann ve Bennett, 2000; Walumbwa ve ark., 2008; Walumbwa, Hartnell ve Oke, 2010) işlem adaleti ile ilgili yapılan çalışmalar, vatandaşlık davranışının ve performansın özellikle işlem adaleti algılarının sonuçları olduğunu göstermektedir. Buna karşın takım arkadaşları ile ilgili olarak takım düzeyinde değerlendirilen işlem adaletinin takım görev performansı ve takım vatandaşlık davranışı ile olan ilişkisi kanıtlanmış olmasına (örn., Cropanzano ve ark., 2011) rağmen, bu ilişkiyi etkileyebilecek potansiyel faktörler henüz incelenmemiştir.

Takım içerisinde meydana gelen davranışlar hakkında takım üyelerinin ortak algısını ifade eden ve gelecekte de nasıl davranılması gerektiği hakkında bir rehber niteliğinde olan takım vatandaşlık davranışı, sosyal etkileşimi düzenlediği ve sosyal kimliği etkilediğinden dolayı örgütsel vatandaşlık davranışından farklı bir kavramdır (Ehrhart, 2004; Ehrhart, Bliese ve Thomas, 2006). Örgütsel vatandaşlık davranışı (örgüte ya da çalışma arkadaşına karşı) bireysel tecrübeyi ifade ederken, takım vatandaşlık davranışı ise takım üyelerinin ortak algılarını ifade etmektedir. Örgütsel vatandaşlık davranışı ile ilgili bireysel düzeyde birçok araştırma yapılmış olmakla birlikte, takım vatandaşlık davranışı hakkında bilinenler oldukça azdır (Ehrhart, 2004). Gerçekleştirilmiş olan birçok çalışmada, işlem adaletinin etkin olduğu yerlerdeki çalışanların örgütsel vatandaşlık davranışlarının yüksek olduğu bulunmuştur. Ancak bu çalışmalar (Ball, Trevino ve Sims, 1994; Moorman ve Blakey, 1995; Shin, Du ve Choi, 2015; Walumbwa ve ark., 2010) bireysel düzeyde yapılmış olup, sadece çalışanların içerisinde bulundukları örgütlerine ya da çalışma arkadaşlarına karşı gerçekleștirdikleri vatandaşlık davranıșını açıklamaktadır. Gerçekleştirilmiş olan az sayıdaki çalışmada (Cropanzano ve ark., 2011; Neumann, 2011), takım arkadaş1 işlem adaleti ve takım vatandaşlık davranışı arasındaki ilişki incelenmiştir. Örgütsel vatandaşlık davranışının bireysel düzeydeki öncülleri kuramsal farkl1lıklardan dolayı takım vatandaşlık davranışını açıklamakta tam anlamiyla yeterli olmamaktadır (Ehrhart, 2004). Başarılı bir takım performansı için takım vatandaşlık davranışı gerekli olduğundan dolayı takım vatandaşlık davranışının öncüllerinin incelenmesinin performans araştırmalarına ek bir değer katacağı düşünülmektedir. Ehrhart'a (2004) göre takım vatandaşlık davranışının öncüllerinden biri çalışanların adalet algılarıdır ve bu adalet algıları takım düzeyinde incelenmelidir.

Yazında belirtildiği üzere ilgili konular ve bunlara bağlı değişkenlere dair takım düzeyinde fazla araştırma yapılmamış olması, bu konularla ilgili yeni araştırmaların gerekliliği ve özellikle takım arkadaşı adaletinin oldukça yeni ama gelecek vaat eden bir kavram olması sebebiyle bu çalışmada, a) takım kolektivizmi inancının takım arkadaşı işlem adaleti, takım görev performansı ve takım vatandaşlık davranışı üzerine etkileri ve b) takım kolektivizmi inancı ile takım görev performansı ve takım vatandaşlık davranışı ilişkisinde takım arkadaşı işlem adaletinin aracılık rolü incelenecektir.

$\mathrm{Bu}$ çalışma ile ilgili belirtilmesi gereken önemli bir nokta ise gerçekleştirilecek olan analizin düzeyidir. Son yıllarda takımlara dair yapılan araştırmalarda kullanılan değişkenlerin takım düzeyinde kümelenmesinin önemi vurgulanmaktadır. Takım üyeleri arasındaki sosyal etkileşim ve yaşanan psikolojik süreçlerin sonucunda takım üyelerinin bireysel olarak elde ettiği deneyimler, algılar, bilişler ya da davranışlar ortak deneyimlere, algılara, bilişlere ya da davranışlara dönüşerek takımın özniteliğini (örn., örgütsel iklim) oluşturmaktadır. Bu nedenle takımın özniteliği, takım düzeyinde (yüksek düzey) bir yap1 olarak değerlendirilmektedir (Kozlowski ve Klein, 
2000). Ayrıca çoklu düzey araştırmacılarına göre, bireysel analiz düzeyinde çalışılan bir yapıyla yüksek analiz düzeyinde (örn., takım düzeyi) kavramsallaştırılan bir yap1 eşdeğer değildir (Bliese, 2000; Morgeson ve Hofmann, 1999). Bu nedenle takım araştırmalarında takımla ilgili kavramların birbirleriyle olan ilişkisini ölçerken bireysel cevapları kullanmaktan ziyade kümeleme işlemini gerçekleştirmek daha güvenilir sonuçların elde edilmesini sağlamaktadır (Bliese, 2000). Bu bağlamda, bireysel olarak verilen cevapların takım düzeyindeki öznitelikleri yansıttığından emin olmak için uygun kuramsal mantık kullanma, takım içi fikir birliğinin görgül olarak kanıtlanması gibi bazı temel kriterler takip edilerek kavramların takım bazında kümelenmesi gerçekleştirilmektedir (Jordan, Feild ve Armenikas, 2002). Bu araştırmada da üretim ve hizmet takımlarının oluşturduğu örneklemden elde edilmiş olan tüm bireysel cevapların kümeleme işlemi için uygun olup olmadığı temel kriterler izlenerek test edilecek ve ilgili değişken başlıkları altında kümelenerek (ortalamaları alınarak) takım düzeyinde analize tabi tutulacaktır.

\section{Kuramsal Çerçeve ve Hipotezler}

$\mathrm{Bu}$ çalışmada, takım kolektivizmi inancı, takım vatandaşlık davranışını ve takım görev performansını etkileyen öncül değişken olarak incelenecektir. Ayrıca bu ilişkide takım arkadaşı işlem adaletinin aracı etkiye sahip olduğu öngörülmektedir. Test edilecek araştırma modeli Şekil 1'de gösterilmiştir.

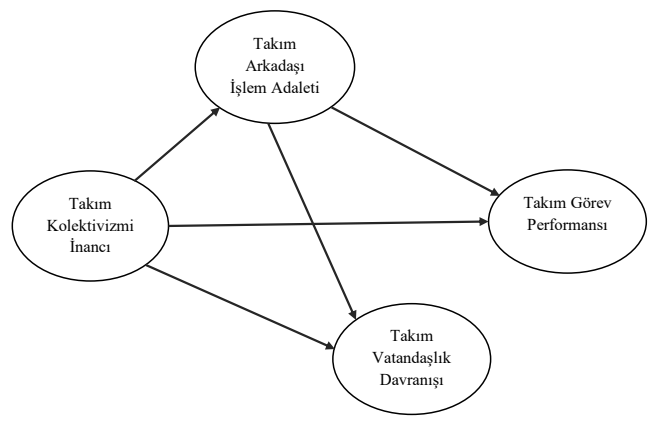

Şekil 1. Araştırma Modeli

\section{Takım Kolektivizmi İnancı}

Toplulukçuluk, Hofstede'nin 1980 yılında Kültürün Sonuçları (Culture's Consequences) isimli çalışmasının yayınlanmasından sonra kültürlerarası psikoloji üzerine çalıșan araştırmacılar tarafından oldukça ilgi gösterilen kavramlardan biri haline gelmiştir. Meksika,
Çin, Japonya ve Türkiye gibi Asya ve Güney Amerika ülkelerinde toplulukçuluğun, ABD, Avusturalya, Birleşik Krallık ve Belçika gibi Batı ülkelerinde ise bireyciliğin yüksek olduğu kabul edilmektedir (Hofstede, 1980). Ancak Triandis'e (1995) göre bireyci olarak kabul edilen kültürlerde oldukça toplulukçu kişiler bulunabileceği gibi, toplulukçu olarak kabul edilen ülke veya kültürlerde de bireyci kişilere rastlamak mümkündür. $\mathrm{Bu}$ çalışmada toplulukçuluk kültürel düzeyde bir yapı olarak değil, psikolojik açıdan kültür içi bireysel farklılıklar olarak ele alınarak takım düzeyinde incelenecektir (örn., Colquitt ve ark., 2002; Dayan ve Çolak, 2008; Eby ve Dobbins, 1997; Kirkman ve Shapiro, 2001).

Takım kolektivizmi inancı, uyum ile iş birliği kavramlarının ne derece önemli takım değerleri olduğuna dair takım üyelerinin ortak algılarını ifade etmektedir ve takım üyeleri için ortak çıkarların ve refahın bireysel çıkarlardan ne derece önce geldiğini göstermektedir (Colquitt ve ark., 2002; Lai, Lam ve Lam, 2013). Birçok kolektif yapı gibi, takım kolektivizmi inancı da bireylerin ortak etkisini temsil etmektedir (Kozlowski ve Klein, 2000; Morgeson ve Hofmann, 1999). Bu nedenle, takım içerisindeki toplulukçuluk eğilimleri yüksek olan bireyler ne kadar fazlaysa, takımın refahı için o kadar fazla iş birlikçi davranışlar sergilenecek, dolayısıyla takım kolektivizmi inancı da yüksek olacaktır (Eby ve Dobbins, 1997; Kirkman ve Shapiro, 2001). Toplulukçuluk eğilimleri yüksek bireyler için içerisinde bulundukları grupların refahı önemli olduğundan bu bireyler grubun çıkarlarına uygun şekilde davranmayı tercih etmektedirler (Wagner, 1995; Wagner ve Moch, 1986). Grubun ihtiyaçları kişisel ihtiyaçlardan veya arzulardan daha önemlidir ve grubun amaçları kişisel amaçlara göre önceliğe sahiptir (Singelis, Triandis, Bhawuk ve Gelfand, 1995; Takano ve Osaka, 1999). Toplulukçuluk, takım üyeleri arasındaki psikolojik mesafeyi azaltan bir faktördür (Earley ve Gibson, 1998) ve kişilerin kendilerini bir grup içerisinde "ben" ya da "biz" olarak görmeleriyle ilgilidir (Hofstede ve Bond, 1984; Triandis, 1995). Toplulukçu eğilimli bireyler kendilerini bilişsel, duygusal ve davranışsal olarak gruplarının bir parçası olarak görürler (Gundlach ve ark., 2006; Markus ve Kitayama, 1991). Triandis'in (1990) bakış açısına göre grup üyeleri ile iyi ilişkiler geliştirmek ve grubun refahı uğruna fedakârlık yapmak bu bireyler için ahlaki bir durumdur. $\mathrm{Bu}$ açıklamalar toplulukçu özelliklere eğilimli bireylerin çoğunlukta olduğu takımlarda "ben" yerine "biz"e önem verildiğini ve böylece iş birliği ve uyumun temel takım değerleri olarak işlev gördüğünü göstermektedir. Ayrıca bu tür takımlarda takım çalışması daha fazla desteklenmektedir (Kirkman ve Shapiro, 2001; Lai ve ark., 2013). 


\section{Takım Arkadaşı İșlem Adaleti}

Takım arkadaşı adaleti, takım çalışması ile ilgili sosyal psikoloji ve işletme yönetimi alanyazınlarından elde edilerek takım düzeyinde bir değişken olarak kavramsallaştırılmıştır (Ambrose ve Schminke, 2009; Cropanzano ve ark., 2011). Takım arkadaşı işlem adaleti, karar verme sürecinde takım üyelerinin ne ölçüde adil işlemler kullandığına dair ortak algıları ifade etmektedir (Cropanzano ve ark., 2011). Cropanzano ve arkadaşları (2011) gerçekleştirdikleri çalışmada, takım arkadaşı adaletine dair bireysel düzeydeki verileri takım düzeyindeki kümelenmiş verilerle kıyasladıklarında bu değişkenin bireysel düzeyde değil, takım düzeyinde incelenmesi gerektiği ve sadece takım düzeyinde takım içerisindeki ortak adalet algılarının net bir şekilde ölçülebildiği sonucuna varmışlardır. Diğer bir ifadeyle, takım arkadaşı işlem adaleti kavramıyla doğrudan bireysel tecrübe değil, takım içerisindeki kişilerin birbirlerine adaletli davranıp davranmadığı hakkındaki ortak algılar incelenmektedir.

Thibaut ve Walker'ın (1975) araştırmasına göre bireylere kendilerini etkileyecek olan işlemlerde söz hakkının verilmesi, işlemlerin adil olarak algılanmasına neden olmaktadır. Leventhal'a (1976) göre ise adil muamele, söz hakkı vermekten daha fazlasını içermektedir ve işlemler her zaman doğruluk, ön yargılı olmama, tutarlılık, düzeltilebilirlik, bütün görüşleri temsil etme ve mevcut etik standartlara uygun olma gibi altı tane kritere bağlı olduğu sürece adil olmaktadır (Cropanzano ve Greenberg, 1997). Takım üyeleri, takım kararlarının alınma şeklinin bireysel ön yargıdan uzak olması, alınan kararların tutarlı olması, takım içerisindeki kişilerin kararlar hakkında duygu ve düşüncelerini ifade edebilmeleri, işlemlerde tam ve doğru bilginin kullanılması ve takımdaki diğer bireylerin göreve olan katkılarının önemsenmesi gibi kriterleri yerine getirmeye çalıştıklarında takım arkadaşı işlem adaleti yüksek düzeyde algılanmaktadır ( $\mathrm{Li}$ ve Cropanzano, 2009). Takım arkadaşı işlem adaleti algısının yüksek olması, takım üyelerinin karar verme sürecini yönetirken adil yöntemler kullandıkları sonucunu ortaya çıkarmaktadır. Bir takım içerisinde takım arkadaŞ1 işlem adaleti düşük olduğunda, bazı takım üyelerinin karar verme sürecinden uzaklaştırıldığı ve izlenebilecek

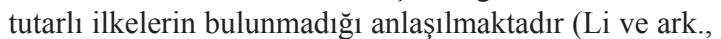
2013).

Bireyler kararların adil bir yöntem ile verildiğini hissederlerse, kendilerini ilgilendiren bir durumun olas1 bir olumsuz sonucunu da kabullenmeye razı olmaktadırlar. Doğal olarak bu durum, bireylerin bekledikleri sonucu alamadıklarında mutlu olacakları anlamına gelmemekte sadece kararlar adil bir şekilde alındığı zaman sonuçları kabullenmeye ve kararlara uymaya razı olduklarını göstermektedir (Burke ve Leben, 2007). Benzer şekilde DeConinck'e (2003) göre işlem adaletinin önem- li sonuçlarından biri süreçte kendilerine söz hakkı verildiğinde ve bir açıklama yapıldığında çalışanların alınan kararları daha olumlu karşılayacak olmalarıdır. Diğer bir ifadeyle, çalışanlar elde ettikleri sonuçlardan ziyade, işlemlerin adil olup olmadığı ile daha fazla ilgilenirler. Adil olmayan davranışlar sosyal dışlanma işareti olduğundan, takım üyesi olan birey diğer takım arkadaşları ile iletişimini azaltabilir ve takım çalışmalarında iş birliği yapmak istemeyebilir. Takım arkadaşları tarafından kendisine adil davranıldığına dair bir tecrübe elde eden takım üyesi ise takım içerisinde kendisini olumlu bir yerde konumlandıracak ve muhtemelen takım çalışmalarında iş birlikçi bir tavır sergileyecektir (Li ve ark., 2013).

\section{Takım Vatandaşlık Davranışı}

Takım düzeyinde vatandaşlık davranışı, yapısında bireysel düzeyde olmayan interaktif elementler (örn., ortak alg1, takım üyelerinin birbirine olan bağlılığ barındırdığından dolayı bireysel düzeydeki örgütsel vatandaşlık davranışından farklıdır. Bireysel düzeydeki vatandaşlık davranışı, bireyin örgüte ya da çalışma arkadaşına karşı olan davranışına odaklanırken, takım düzeyindeki vatandaşlık davranışı ise takım içerisindeki takım üyeleri tarafından sergilenen ortak vatandaşlık davranışı anlayışı üzerine odaklanmaktadır. Takım vatandaşlık davranışı, takım üyeleri arasındaki etkileşim yoluyla geliştirilen, davranış için rehberlik sağlayan ve sosyal kimliği etkileyen grup normları olarak işlev görmektedir. $\mathrm{Bu}$ nedenle takım vatandaşlık davranış1nın, takım düzeyinde incelenmesi için makul bir takım içi anlayışa sahip olması gerekmektedir (Ehrhart, 2004; Ehrhart ve Naumann, 2004).

Takım vatandaşlık davranışı, takım üyelerinin birbirlerine yardım etmek için gösterdiği gönüllü davranışlardır (Organ, 1988). Tıpkı örgütlerin örgütsel vatandaşlık sergileyen çalışanlara ihtiyaç duydukları gibi takımlar da takım işlevinin başarılı bir şekilde yerine getirilebilmesi için takım vatandaşlık davranışı gösteren çalışanlara ihtiyaç duymaktadırlar (Randel, 2003). Cropanzano ve arkadaşları (2011), Van der Vegt, Van de Vliert ve Oosterhof (2003) tarafından yapılan çalışmayı göz önünde bulundurarak yaptıkları araştırmada, takım vatandaşlık davranışını belirleyebilmek için örgütsel vatandaşlık davranışının sosyal takım süreciyle ilgili olan "yardım etme" ve "sadakat" boyutlarını ele almışlardır. Takım bağlamında yardım etme davranışı, takımla ilgili iş ve problemlerde ne ölçüde yardımlaşma gerçekleştiğine dair takım üyelerinin ortak algılarını ifade etmektedir. Sadakat ise, takımın başarısı için takım içerisinde ne derecede ekstra zaman harcandığ1 ve çaba gösterildiğine dair takım üyelerinin ortak algılarını ifade etmektedir. Çalışanlar kendilerine iyi niyet gösteren kişilerle uzun vadeli sosyal etkileşimde bulunmaktadırlar (Cropanzano 
ve Mitchell, 2005). Ayrıca, takımın bir parçası olarak da takım arkadaşlarına daha fazla destekte bulunmaya istekli olmaktadırlar (Cropanzano ve ark., 2011).

\section{Takım Kolektivizmi İnancı ve Takım Arkadaşı İşlem Adaleti}

Bireysel düzeydeki değişkenlerle takım düzeyindeki değişkenler yapısal olarak birbirlerinden farklı olduklarından dolayı diğer değişkenlerle olan fonksiyonel ilişkileri aynı değildir (Bliese, 2000). Kültürel bir kavram olarak ele alınan çalışmalarda bireycilik ve toplulukçuluğun bireysel algılar üzerinde genellikle düzenleyicilik etkisi incelenirken (örn., Erdogan ve Liden, 2006; Özbek, Yoldash ve Tang, 2016), takım kolektivizmi inancının takım içerisindeki iklime (takım düzeyindeki biliş) doğrudan etkisinin olduğu görülmektedir (örn., Colquitt ve ark., 2002; Dayan ve Çolak, 2008).

Genel olarak, toplulukçu ya da bireyci diye ayırmaksızın tüm bireyler için adalet önemlidir (Lind ve Earley, 1992). Ancak işlem adaletinin işleyiş mekanizması toplulukçu ve bireyci özelliklere eğilimli bireyler için farklılık göstermektedir. Bireycilerin her zaman kendi çıkarları ön plandadır (Triandis, 1990). Kişisel çıkar modeline göre birey kişisel çıkarını artırmak için karar verme sürecine odaklanmaktadır. İşlemler bir sonuca varmak için araç olarak görülmektedir ve varılacak sonuç bireysel kazancı artıracak yönde olmaktadır (Lind ve Tyler, 1988). Bu nedenle bireyciler kendi çıkarları korunduğu sürece işlemleri adil olarak algılayabiliyorken (Triandis, 1990), toplulukçular "ben" yerine "biz" ifadesini kullanan bireyler (Triandis, 1995) olarak takım içerisindeki bir kişiye yapılan haksızlığı tüm takıma yapılmış gibi algılayabilmektedirler. Dolayısıyla, takım üyeleri takım içerisinde işlem adaletsizliği olduğuna dair takım düzeyinde biliş geliştirebilirler (Naumann ve Bennett, 2000).

Bir görevin başarılı bir şekilde gerçekleştirilebilmesi için o görevi kendisinin yerine getirmesi gerektiğini düşünen bireyciler, kazanma odaklı rekabetçi kişilerdir. Başkalarının göreve olan katkısını önemsemezler ve başkalarının fikirlerini almaktan ziyade kendileri karar vermek isterler. Bu durum toplulukçular için tersinedir. Toplulukçu eğilimli bireyler bireysel rekabetten uzak, görevin başarılı bir şekilde yerine getirilmesi için takımdaki diğer kişilerin fikirlerinin de alınması gerektiğini düşünen iş birlikçi bireylerdir (Triandis, Bontempo, Villareal, Asai ve Lucca, 1988). Earley ve Gibson'a (1998) göre toplulukçuluk, takım üyeleri arasındaki psikolojik mesafeyi azaltan bir faktördür. Kişiler arasında psikolojik mesafenin az olması etik dışı kararların verilmesini engellemektedir (Wood, Noseworthy ve Colwell, 2013). Ayrıca, toplulukçu takımlarda karar verme sürecine tüm takım üyelerinin katılımını sağlayan sistemler mevcuttur
(Earley ve Gibson, 1998). Takım üyelerinin katılımını sağlayan ve karar verme kurallarının tam olarak uygulandığı sosyal bir çevre, işlem adaleti algısının yüksek olmasını sağlamaktadır (Leventhal, 1976). Bu nedenle takım kolektivizmi inancının, takım içerisindeki takım arkadaşı kaynaklı işlem adaleti algısının da yüksek olmasına neden olabileceği düşünülmektedir.

Toplulukçuluk eğilimleri yüksek olan takım üyeleri, takım içerisinde uyum ve dayanışmayı geliştiren işlemleri tercih etmeye daha yatkındırlar (Earley ve Gibson, 1998). Sugawara ve Huo (1994) bireycilik-toplulukçuluğun işlem adaletini nasıl etkilediğine dair gerçekleştirdikleri çalışmada, toplulukçuluğa eğilimli bireylerin kişilerarası ilişkilerinde uyumu korumak adına işlem adaletine olan ilgilerini feda edebileceklerini öngörmüşlerdir. Ancak elde edilen bulgular toplulukçu bireylerin önemli bir sorun karşısında çatışmayı önlemek amacıyla işlem adaletinin 'işlemlerin açık olması' kriterine önem verdiklerini göstermiştir. Bu nedenle toplulukçuluk eğilimli bireylerin çoğunlukta olduğu takımlarda, takım üyelerinin takım içerisinde uyumu sağlayabilmek ve çatışmayı önleyebilmek için işlem adaletine önem vereceklerini ve böylece takım arkadaşı işlem adaleti algısının da yüksek olacağını söylemek yerinde olacaktır.

Takım kolektivizmi inancının işlem adaleti ikliminin öncüllerinden biri olduğunu destekleyen çalıșmalar bulunmaktadır. Colquitt ve arkadaşları (2002) tarafından gerçekleştirilen çalışmada, takım kolektivizmi inancının takım düzeyindeki işlem adaleti ikliminin öncülü olduğu tespit edilmiştir. Benzer şekilde Dayan ve Çolak (2008) yeni ürün geliştirme takımları üzerine yaptıkları araştırmada, takım kolektivizmi inancının işlem adaleti iklimini olumlu yönde etkilediğini bulmuşlardır. Yukarıda ifade edilen araştırmaların ışığında oluşturulan hipotez şu şekildedir;

Hipotez 1: Takım kolektivizmi inancı, takım arkadaşı işlem adaletini pozitif yönde yordamaktadır.

\section{Takım Kolektivizmi İnancı ve Takım Vatandaşlık Davranışı}

Toplulukçuluk eğilimleri yüksek olan bireyler, diğer takım üyeleri ile güçlü ilişkiler geliştirmekte ve birbirlerine karşı bağlılık hissetmektedirler. Ayrıca bu bireyler, takımın görevlerini yerine getirirken iş birlikçi davranış sergileyerek, üyesi oldukları takıma uyum sağlamaya özen göstermektedirler (Bond, Leung ve Wan, 1982; Singelis ve ark., 1995). Gomez-Mejia ve Wellbourne'e (1991) göre toplulukçuluk eğilimleri yüksek olan bireyler için takımın başarısı, gruba bağlı olma, başkaları için fedakârlıkta bulunma ve etik ilkelere bağlılık gibi ölçütler önem taşımaktadır. Toplulukçuluk eğilimli bireylerin ait oldukları gruba sıkı bir şekilde bağlı olmalarından dolayı bu kişiler arasında örgütsel vatandaşlık 
davranışı daha fazla görülmektedir (Paine ve Organ, 2000; Parkes, Bochner ve Schneider, 2001). Toplulukçu değerlere sahip çalışanlar, işin kendisinden ziyade öncelikle iş arkadaşlarına ya da yöneticilerine olan bağlılıklar1 nedeniyle kendilerini örgütlerine adamaktadırlar. Finkelstein (2012) yaptığı çalışmada toplulukçuluk eğilimli çalışanların, bireyci çalışanlara göre çalışma arkadaşlarına karşı daha güçlü vatandaşlık davranışı gösterdiklerini bulmuştur. Finkelstein (2014) işle ilgili sorunlarda toplulukçuluk eğilimi yüksek olan çalışanların çalışma arkadaşlarına daha fazla yardım ettiklerini gözlemlemiştir. Ramamoorthy ve Flood (2004) yüksek düzeyde bireyciliğin vatandaşlık davranışının alt boyutlarından takım sadakatini ve çalışanların birbirlerine yardım etme davranışını negatif yönde etkilediğini bulmuşlardır. Bireyci çalışanlar kendi çıkarlarına bir katkısı olacaksa çalışma arkadaşlarının yaptığı işe yardım etmektedirler. Buna karşın, toplulukçu eğilimli bireyler kendi çıkarlarına bir katkısının olup olmadığına ya da takım içerisindeki görevlerinin tamamlanmasının başka bir çalışanın yaptığ 1 işe bağlı olup olmamasına bakmaksızın gönüllü olarak çalışma arkadaşlarına yardım etmektedirler. $\mathrm{Bu}$ üyeler yardım etme davranışını takım üyesi olmanın bir parçası olarak algıliyor olabilirler. Murphy, Ramamoorthy, Flood ve MacCurtain (2006) yaptıkları çalışmada bireyciliğin yardım etme ve takım sadakat davranışı ile olan ilişkisinin negatif yönde olduğunu bulmuşlardır. Bireyciler, ancak ücretlendirme açısından eşitlik söz konusu olduğunda takım çalışmasına katkıda bulunmakta kendilerini zorunlu hissetmektedirler. Jackson, Colquitt, Wesson ve Zapata-Phelon (2006) tarafindan yapılan çalışmada, psikolojik toplulukçuluğun takımlarda görev alan çalışanların vatandaşlık davranışlarını pozitif yönde etkilediği bulunmuştur. Ancak söz konusu çalışmalar bireysel düzeyde gerçekleştirilmiştir. Gerçekleştirilmiş olan bu görgül çalışmalar temel alınarak bireylerin takım içerisindeki davranışları göz önünde bulundurulduğunda, toplulukçu eğilimli bireylerin çoğunlukta olduğu takımlarda iş birliği, takım desteği, yardım etme davranış1 ve takımlarına karşı sadakat daha fazla sergileneceğinden dolayı takım vatandaşlık davranışı da yüksek olacaktır. Yukarıda ifade edilen bilgiler 1şığında oluşturulan hipotez şu şekildedir:

Hipotez 2: Takım kolektivizmi inancı, takım vatandaşlık davranışını pozitif yönde yordamaktadır.

\section{Takım Kolektivizmi İnancı ve Takım Görev Performansı}

Earley $(1989,1993,1994)$ yaptığ1 çalışmalarda, bireyci kişilerin ortak bir sorumluluk almadan kendi başlarına çalıştıklarında daha fazla performans gösterdiklerini, buna karşın toplulukçuluk eğilimleri yüksek olan bireylerin ise daha fazla ortak sorumluluk üstlenerek takım içerisinde daha iyi performans gösterdiklerini tes- pit etmiştir. Drach-Zahavy’e (2004) göre çoğunluğunu toplulukçu bireylerin oluşturduğu takımlarda, bireycilerin çoğunlukta olduğu takımlara göre takım arkadaşları arasında iş yükü fazla olana yardım edildiği, herhangi bir sorunun vuku bulması halinde alternatifler üretildiği görülmektedir. Ayrıca, toplulukçu eğilimli kişiler takım arkadaşlarına duygusal ve bilgisel açıdan daha fazla destek sağlamaktadırlar. Burada duygusal destek, takım arkadaşına tavsiyelerde bulunmayı ya da onu yönlendirmeyi değil, cesaretlendirici sözler söylemeyi, ağlayabileceği bir omuz olmayı ve acısını paylaşabilmeyi ifade etmektedir. Bilgisel destek ise işin yürütülmesi için gerekli olan bilginin takım arkadaşları arasında paylaşılmasını ifade etmektedir. Böylece, takım içinde ne kadar fazla destek varsa, takımın görev performansı da o derecede başarılı olmaktadır.

Erez ve Somech (1996) ise takımın belirli bir hedefi olmasa bile takım içerisindeki kolektif benlik değerlerine sahip olan kişilerin yüksek performans gösterdiklerini bulmuşlardır. Öte yandan bireyci kişiler takımın belirli bir hedefi yoksa düşük üretkenlik sergilemektedirler. Gundlach ve arkadaşları (2006) bireylerin belirli gruplarla özdeşleşme sürecini açıklayan sosyal kimlik kuramı ve grup içerisindeki bireylerin birbirlerini nasıl algıladıkları ile ilgili süreci açıklayan sosyal ilişkiler modelini temel alarak toplulukçuluk-bireyciliğin takım performansı üzerindeki etkisini açıklamışlardır. Araştırmada incelenen takım performansı, çalışanların takım görevlerini birlikte sürdürebilme ve ürün ya da hizmetle ilgili takım görevlerini yerine getirebilme kapasitesini ifade etmektedir. Bu araştırmacılara göre takımın toplulukçu ya da bireyci eğilimli kişilerden oluşması takım özdeşleşme derecesini doğrudan etkilemektedir. Takım bağlamında toplulukçular, bilişsel, davranışsal ve duygusal olarak takım ile özdeşleşerek takım çıkarları için hareket etmektedirler. Sosyal gruplara pek değer vermeyen bireycilerin ise takım ile özdeşleşmeleri toplulukçulara göre daha güçtür ve bireysel çıkarları önceliklidir. Takım özdeşlemesi güçlü olduğunda, takım çalışmasına motive ettiğinden ve başarıya ulaşmayı sağladığından dolayı takım performansı için elzem olan takım kimliği de güçlü olmaktadır. Ayrıca sosyal ilişkiler modeline göre takım içi algılar, takım kimliğini kuvvetlendirmekte ya da zayıflatmaktadır. Birey, takım tarafından kontrolcü ya da baskıcı olarak görüldüğü halde destekçi olarak algılandığını düşünürse aynı şekilde davranmaya devam edecek ve bu da takım içinde gerilimin artmasına ve takım kimliğinin zayıflamasına sebebiyet vererek takım performansını olumsuz yönde etkileyecektir. $\mathrm{Bu}$ nedenle, bireyci takım üyelerinin çoğunlukta olduğu takımlarda takım görev performansı daha düşük olurken, toplulukçu bireylerin çoğunlukta olduğu takımlarda takım görev performansı daha yüksek olacaktır. 
Takım düzeyinde gerçekleştirilen önceki çalışmalarda takım kolektivizmi inancının, takımın etkinliğini (Kirkman ve Shapiro, 2001) ve takım iş birliği aracılığıla takım performansını pozitif yönde etkilediği sonucuna ulaşılmıştır (Eby ve Dobbins, 1997). Ayrıca Bell'in (2007) gerçekleştirdiği meta-analiz çalışma (takım düzeyinde), takım kolektivizmi inancının takım performansına orta derecede pozitif etkisinin olduğunu göstermiştir. Bu bağlamda yukarıda ifade edilen araştırmalara dayanarak oluşturulan hipotez şu şekildedir:

Hipotez 3: Takım kolektivizmi inancı, takım görev performansını pozitif yönde yordamaktadır.

\section{Takım Arkadaşı İşlem Adaleti ve Takım Görev Performanst}

İş görenler işlem adaleti algıları yüksek olduğunda takımlarına daha bağlı ve takım üyeleri adına daha fazla fedakâr olmaya istekli olmaktadırlar. Ayrıca işten ayrılma niyetleri daha düşüktür (Cropanzano ve Schminke, 2001). İşlem adaletinin kriterlerinden biri olan kararlarda söz sahibi olma hakkı çalışanlara tanınmadığında bireylerin motivasyonlarında azalma görülmekle birlikte moral bozukluğu da ortaya çıkmakta ve sonuç olarak düşük performans sergilenmesine yol açmaktadır (Gümüşlüoğlu ve Karakitapoğlu-Aygün, 2010). Lind ve Tyler'a (1988) göre işlem adaleti, kişilerin kısa dönemli çıkarlarının yerine bağlı oldukları grubun ya da örgütün çıkarları için çalışmalarına ve hatta kendilerinden istenileni fazlasıyla yerine getirmekte istekli olmalarına neden olan bir faktördür. Bu nedenle işlem adaleti, iş takımlarının etkinliğini artıran bir unsurdur.

Cropanzano ve arkadaşları (2011), takım arkadaşı adaletinin, takım çalışması süreci aracılığıyla bireylerin etkin performans sergilemelerine yol açtığını bulmuşlardır. Takım içerisindeki adalet algıları takımların çalışma süreçlerini etkilemekte ve böylece takımların çalışma süreçleri de elde edilen sonuçların etkinliğini azaltıcı ya da artırıcı şekilde rol oynamaktadır. Molina ve arkadaşları (2017), takım arkadaşı adaletinin örgütsel adalet iklimi kadar olmasa bile performansı etkileyebileceğini belirtmişlerdir.

Örgüt içerisindeki yetkili kişilerin yanı sıra takım üyelerine arkadaşları tarafından adil bir şekilde davranıldığında ve takımın genelinde herkese adil davranıldığına dair bir fikir birlikteliği oluştuğunda takım üyeleri çalışma ortamlarından memnun olabilmekte ve bu durum da takım üyelerinin performansına katkıda bulunabilmektedir (Li ve ark., 2013). Bu bilgiler 1şığında oluşturulan hipotez şu şekildedir:

Hipotez 4: Takım arkadaşı işlem adaleti, takım görev performansını pozitif yönde yordamaktadır.

\section{Takım Arkadaşı İşlem Adaleti ve Takım Vatandaşlık Davranışı}

Gerçekleştirilen birçok çalışmada, işlem adaletinin olduğu yerde çalışanların örgütsel vatandaşlık davranış1nın da yüksek olduğu ortaya konulmuştur (Cropanzano ve Schminke, 2001). Takım üyeleri arasında artan işlem adaleti algısı, kişilerin birbirlerine yardım etme davranışını açıklamaktadır (Naumann ve Bennett, 2000). İşlem adaleti algısının düşük düzeyde olması, çalışanların takıma olan bağlılıklarını olumsuz etkilemekte (Rhoades, Eisenberger ve Armeli, 2001) ve birbirlerine yardım etmekte isteksiz olmalarına neden olmaktadır (Ehrhart, 2004; Spector ve Fox, 2002). Niehoff ve Moorman'e (1993) göre takımda yüksek işlem adaleti olması halinde, takım üyeleri takımın refahı için yardım etme davranışında bulunabilmektedirler. Korsgaard, Schweiger ve Sapienza'ya (1995) göre işlem adaleti algısı, takıma dair bağlılığı artırmaktadır. Takım üyelerinin birbirlerine olan bağlılığı, takımın işlevselliğini sürdürebilmesi için son derece önemlidir. Brockner ve Wiesenfeld (1996), takım içerisinde işlem adaletsizliği hissedildiğinde bireylerin kendilerine karşı saygısızlık yapıldığını düşündüklerini ve bu nedenle bağlılıklarının da negatif yönde etkilendiğini ileri sürmüşlerdir. Bu negatif etki, takım üyeleri arasında vatandaşlık karşıtı davranışlara neden olmaktadır (Pearce ve Giacalone, 2003).

Cropanzano ve arkadaşları (2011) ve Neumann (2011) yaptıkları çalışmada takım arkadaşı işlem adaletinin takım çalışma süreçlerine olan olumlu etkisinin takımın vatandaşlık davranışını da pozitif yönde etkilediğini bulmuşlardır. Benzer şekilde bu çalıșmada da takım arkadaşı işlem adaleti algısının, takım vatandaşlık davranışını etkileyebileceği ileri sürülmektedir.

Hipotez 5: Takım arkadaşı işlem adaleti, takım vatandaşlık davranışını pozitif yönde yordamaktadır.

\section{Takım Arkadașı İşlem Adaletinin Aracılık Rolü}

Triandis ve Bhawuk'a (1997) göre toplulukçuluk eğilimleri yüksek olan bireyler durumlara göre ilişkiler geliştirebilen, aldıklarından daha fazlasını verebilen ve uzun dönemli öngörüde bulunabilen bireylerdir. Ayrıca takımları ile ilgilenmeye istekli olmakla birlikte bireyci kişilere göre daha fazla duygudaşlık gösterebilmektedirler. Bu nedenle toplulukçu eğilimli bireyler sosyal değişim zihniyetine uygun bireylerdir. Takım arkadaşları en iyi sosyalleşme aracı olduğundan dolayı takım üyeleri, takım değerlerini ihlal eden özel durumları ve bu özel durumlara karşı nasıl davranacaklarını birbirlerinden öğrenirler. Takım üyelerinin paylaştıkları ortak algılar (örn., çalışma arkadaşlarının adil davranışı) ve takımda fikir birliğini oluşturan işlemler takım üyeleri arasında güven inşa etmektedir (Randel, 2003; Walumbwa, Hartnell ve Misati, 2017). Birbirlerine güven duyan takım üyeleri de işle ilgili 
sorumlulukları yerine getirerek ve takım için en iyisini yaparak takım vatandaşlık davranışını yerine getirmektedirler (Randel, 2003). Benzer şekilde Konovsky ve Pugh'a (1994) göre adil işlemler, haklara saygı duyulduğunun ve değer verildiğinin bir göstergesi olarak çalışanlarda sadakat ve güven duygusunu geliştirdiği için vatandaşlık davranışını pozitif yönde etkilemektedir. Ayrıca işlem adaleti, grubun refahını artırdığı için takımlarda ortak çıkarları koruyan gönüllü davranışlar olarak da tanımlanan vatandaşlık davranışını güçlendirmektedir (Moorman ve ark., 1993). Ortak çıkarlar, adil işlemlere karşı duyarlıdır ve toplulukçuluktan beslenmektedir (Moorman ve Blakey, 1995). Bu nedenle, takım içerisinde olumsuz işlem adaleti algısı oluştuğunda takım vatandaşlık davranışında da azalma görülmektedir (Naumann ve Bennett, 2000).

Hipotez 6: Takım arkadaşı işlem adaletinin, takım kolektivizmi inancı - takım vatandaşlık davranışı ilişkisinde aracılık rolü vardır.

Toplulukçu eğilimli bireyler üyesi oldukları grupların dışında yer alan kişilerden daha çok kendilerinin ait olduğu grubun üyesi olan kişilerle iletişim kurarlar ve ait oldukları grup ile özdeşleşirler. "Ben" yerine "biz" ifadesini telaffuz ederler (Triandis, 1995). Bu yüzden toplulukçu kişiler, takım içerisindeki adalet kişiden kişiye farkl1lık gösterdiğinde büyük olasılıkla bunu hemen fark edeceklerdir (Colquitt, 2004). Takım arkadaşı işlem adaletinin düşük olduğunu hissettiklerinde ise kendilerini dışlanmış olarak görebilir ve bu nedenle de takım sadakatini destekleyecek davranışlarda bulunma, yeterince emek ortaya koyma, birbirlerine yardım etme gibi kişilerarası süreçlerde sergilenmesi gereken olumlu davranışları sergilemeyebilirler (Cropanzano ve ark., 2011). Takımdaki işlem adaleti algısı yüksek olduğunda, toplulukçu özelliklere eğilimli bireylerin çoğunlukta olduğu takımların performansı da yüksek olacaktır (Colquitt, 2004).

Kişinin işlem adaleti algısı işe harcadığı emeğin derecesini etkileyebilir (Liden, Wayne, Jaworski ve Bennett, 2004). Earley (1989) yaptığı çalışmada, toplulukçu kişiler arasında sorumluluk derecelerine bakılmaksızın sosyal kaytarmanın olmadığını bulmuştur. Takım arkadaŞ1 işlem adaletinin takım üyeleri arasında sosyal kaytarmay1 azaltmasından dolayı takım performansına olumlu etkileri bulunmaktadır (Price, Harrison ve Gavin, 2006). Takımın toplulukçu davranışı, takım üyelerinin katkılarının önemsendiği, iş yükünün bölüşüldügü, takım içerisinde alternatif görüşlere yer verildiği ve gerekli bilginin takım üyeleri arasında paylaşıldı $\breve{1}$ bir iş ortamı sağladığ için takımın performansını artırmaktadır (Watson, Johnson ve Merritt, 1998). Bu çalışmalardan yola çıkarak oluşturulan hipotez şu şekildedir:

Hipotez 7: Takım arkadaşı işlem adaletinin, takım kolektivizmi inancı - takım görev performansı ilişkisinde aracılık rolü vardır.
Yöntem

\section{Örneklem}

Araştırmanın örneklemini 93 takımda çalışan 560 kişi oluşturmaktadır. Takımlar İstanbul, İzmir, Kocaeli ve Mersin illerinde yer alan, üretim ve hizmet sektöründe faaliyet gösteren işletmelerde çalışan kişilerden oluşmaktadır. Örneklemin dağılımına cinsiyet açısından bakıldığında katılımcıların \%36'ısı kadınken, \%64'ü erkektir. Takım çalışanlarının yaş ortalaması $32.7(S=$ 8.16) ve takımlardaki ortalama çalışma süresi $3.3(S=$ 3.26) yıldır. Çoğunluğunu \%40 ile 7-10 kişilik çalışanlara sahip olan takımlar oluşturmaktayken, \%24'ünü 10 kişiden fazla, \%19'unu 2-4 kişilik ve son olarak da \%17'sini 5-6 kişilik ( $S=.50)$ çalışanlara sahip olan takımlar oluşturmaktadır. Ayrıca tüm katılımcıların \%89'u lisans, \%11'i lisansüstü mezunudur.

\section{Veri Toplama Araçları ve Değişkenler}

$\mathrm{Bu}$ araştırmada veri toplama aracı olarak anket tekniği kullanılmıştır. Araştırmada kullanılan tüm değişkenler 5'li Likert ölçeği ile ölçülmüştür. Katılımcılar 1 (kesinlikle katılmıyorum)'dan 5 (kesinlikle katılıyorum)'a sıralanan seçenekleri işaretlemişlerdir. Bu çalışmada kullanılan tüm ölçekler, araştırmacılar tarafından Brislin'in (1970) kültürlerarası kullanımlar için önerdiği çeviri-geri çeviri yöntemi esas alınarak Türkçeye uyarlanmıştır. Ayrıca, aynı ölçekler 3 hafta arayla ikinci kez 12 takımda çalışan 58 kişi tarafından tekrar cevaplanmış ve elde edilen veri ile test-tekrar test güvenirliği hesaplanmıştır. Test-tekrar teste katılan örneklemin \%45'i kadın, \%55'i erkektir. Yaş ortalaması $34.6(S=8.84)$ ve takımlardaki ortalama çalışma süresi $3.5(S=2.94)$ yıldır. Örneklemin \%16'sını 2-4 kişilik, \%43'ünü 5-6 kişilik ve \%41'ini 7-10 kişilik $(S=.71)$ takımlar oluşturmaktadır. Ayrıca test-tekrar teste tabi tutulan katılımcıların \%83'ü lisans, \%17'si lisansüstü mezunudur.

Takım Arkadaşı İşlem Adaleti. Takım Arkadaşı İşlem Adaleti, Leventhal'ın (1976) önerdiği kriterlere dayanarak Li ve Cropanzano (2009) tarafından geliştirilen 5 maddeli ölçek kullanılarak ölçülmüştür (Örnek madde: "Takımımızda kararların alınma şekliyle ilgili duygu ve düşüncelerimizi ifade edebiliyoruz"). Takım arkadaşı işlem adaleti için takım üyelerinden elde edilen cevapların ortalamaları kullanılmıştır. Bu araştırmada, ölçeğin Cronbach alfa güvenirlik katsayısının .91 ve test-tekrar test güvenirliğinin $.96(p=.01)$ olduğu bulunmuştur.

Takım Kolektivizmi Inancı. Takım Kolektivizmi inancı Wagner (1995) tarafından geliştirilen 6 maddeli ölçek ile ölçülmüştür (Örnek madde: "Takımdaki kişiler takımın iyiliği için fedakârlık yapmaya istekli olmal1dır"). Takım kolektivizmi inancı için takım üyelerinin 
verdiği cevapların ortalamaları kullanılmıştır (Colquitt ve ark., 2002). Bu çalışmada, ölçeğin Cronbach alfa güvenirlik katsayısının .87 ve test-tekrar test güvenirliğinin $.97(p=.01)$ olduğu bulunmuştur.

Takım Görev Performansı. Takım görev performansını ölçmek için Goodman ve Svyantek (1999) tarafindan geliştirilen 9 maddeli görev performans ölçeği kullanılmıştır. Takım görev performansı, bölüm yöneticileri tarafindan takım düzeyinde değerlendirilmiştir. Takımların aldıkları yüksek puanlar, takımın görev performansının yüksek olduğunu göstermektedir (Örnek madde: "Takım üyeleri iş hedeflerini yerine getirmişlerdir"). Ölçeğin Cronbach alfa güvenirlik katsayıs1 .86 olarak bulunmuştur.

Takım Vatandaşlık Davranışı. Önceki araştırmalara (Cropanzano ve ark., 2011; Van der Vegt ve ark., 2003) bağlı kalarak takım vatandaşlık davranışını ölçmek için örgütsel vatandaşlık davranışının sosyal takım süreci ile ilgili yardım etme ve sadakat davranışı boyutlarına odaklanılmıştır. Yardım etme davranışı için 4 madde (Örnek madde: "Takım üyeleri ağır iş yükü olanlara yardım ederler") ve sadakat davranışı için 3 maddeden (Örnek madde: "Takım üyeleri iş için ekstra sorumluluk ve görev almaktan kaçınmazlar") oluşan, Cropanzano ve arkadaşları (2011) tarafindan Van der Vegt ve arkadaşlarının (2003) çalışması temel alınarak takım düzeyine uyarlanan ölçek kullanılmıştır. Takım vatandaşlık davranışı için takım üyelerinin verdiği cevapların ortalamaları kullanılmıştır. Bu çalışmada yardım etme ve takım sadakati boyutları için test-tekrar test güvenirliği sirasiyla .93 ve $.98(p=.01)$ olarak bulunmuştur.

Bu ölçekte iki alt boyut arasındaki yüksek korelasyon nedeniyle ayrışma geçerliği sağlanamadığından dolayı tüm maddeler tek bir boyutta toplanmıştır (açıklanan varyans, $\% 77$, maddelerin faktör yükleri .82 ve .93 arasındadır). O'Brien (2007) ve York (2012), iki değişken arasındaki yüksek korelasyonun yüksek VIF değerine yol açmasından dolayı kuramsal olarak herhangi bir sakınca ortaya çımayacaksa bu iki değişkenin birleştirilmesini önermektedir. Randel'in (2003) bu çalışmada ele alınan iki alt boyuta ait ölçek maddelerinin bir özetini de veren, Organ'ın (1988) örgütsel vatandaşlık davranışı tanımını esas alarak oluşturduğu tek maddeli bir ölçekle takım vatandaşlık davranışını ölçtüğü göz önünde bulundurulmuş, yardım etme ve takım sadakati ölçekleri birleştirilerek takım vatandaşlık davranışı ölçeği elde edilmiştir. Bu çalışmada, ölçeğin Cronbach alfa güvenirlik katsayısının .95 olduğu bulunmuştur.

\section{İşlem}

$\mathrm{Bu}$ araştırmada yapısal model, kısmi en küçük kareler (PLS) analizi ile test edilmiştir. Kovaryans esaslı YEM teknikleri gibi (örn., AMOS, EQS, LISREL, MP-
LUS), PLS de ölçüm modelini ve yapısal teorik modeli eş zamanlı olarak hesaplayan ikinci nesil bir istatistik tekniğidir (örn., SmartPLS, WarpPLS). Kovaryans esaslı algoritmalardan farkı, varyans odaklı olması ve kü̧̈ük örneklem ile çalışmaya izin vermesidir (Chin, 1998; Naranjo-Gil, Hartmann ve Maas, 2008; Wong, 2013). Ayr1ca PLS-YEM, küçük örneklem ile birçok madde ve aracı değişkene sahip karmaşık modelleri incelemek için uygun bir yöntemdir (Chin, 1998; Tenenhaus, Vinzi, Chatelin ve Lauro, 2005). Bu nedenle, küçük örnekleme sahip, takım düzeyinde yapılan araştırmalarda PLS-YEM yöntemi yaygın bir şekilde kullanılmaktadır (örn., Goffnett, 2017; Hoch ve Kozlowski, 2014; Mitchell, Boyle ve Van Stieglitz, 2018; Mitchell, Parker, Giles, Joyce ve Chiang, 2012; Naranjo-Gil ve ark., 2008; Palanski, Kahai ve Yammarino, 2011; Tabassi, Roufechaei, Bakar ve Yusof, 2017). Bu çalışmada araştırmanın verileri, IBM SPSS 24 ve bootstrapping yeniden-örnekleme yöntemi ile analiz yapan SmartPLS (v. 3.2.7) paket programları kullanılarak test edilmiştir. Bootstrapping yeniden-örnekleme yöntemi ile orijinal verinin yerine rastgele seçilmiş 1000 alt-örneklem vakası olușturulmuştur (Chin, 1998).

Veri Kümeleme. Kozlowski ve Klein (2000) araştırmacıların çalışmalarında kullandıkları kuram düzeyi ile ölçüm düzeyini net bir şekilde belirlemeleri gerektiğini ileri sürmüştür. Kuram düzeyi, açıklamaya çalışılan hedefi (örn., birey, takım ya da örgüt) tanımlamaktadır. Ölçüm düzeyi ise veri kaynağını tanımlamaktadır (örn., bireylerin verdikleri cevapların ortalamalarının kullanılması). Bu çalışmada, kuram düzeyi takımdır ve araştırmaya dâhil olan bütün yapılar takım düzeyinde kavramsallaştırılmıştır. Takım düzeyinde kümelenen veriler takım düzeyindeki yapıların ölçümünün daha güvenilir olmasına imkân vermektedir (Bliese, 2000). Grup-içi katılımcılar arasındaki uyuşma katsayısının $\left(\mathrm{r}_{\text {wg(i) }}\right)$ yeterli düzeyde olması Likert ölçeğinde bireysel düzeydeki cevapları takım düzeyinde toplamak için ön koşuldur (James, Demaree ve Wolf, 1984). Bu nedenle eşik değeri .70 olan $r_{\text {wg(i) }}$ değeri hesaplanmıştır (LeBreton ve Senter, 2008). Elde edilen bulgulara göre $r_{w g(j)}$ değerleri; takım arkadaşı işlem adaleti için .83, takım kolektivizmi inancı için .84 , takım vatandaşlık davranışı için .82'dir. Bütün $r_{w g(j)}$ değerleri .70’ten yüksek olduğundan dolay1 kümeleme için yeterli uyuşma katsayısı mevcuttur. Ayrıca takım-içi ve takımlar arası varyansı değerlendirmek için sınıf-içi korelasyon katsayıları ICC(1) ve ICC(2) hesaplanmıştır. ICC(1) her takım içerisindeki bireylerin cevaplarının güvenirliğini ifade etmektedir. ICC(2) takım düzeyindeki ortalamaların güvenirliğini göstermektedir (Bliese, 1998). ICC(1) ve ICC(2) kullanılarak yapılan kümelemelerde kesin bir standart olmamasına rağmen .05 ile .30 arasındaki ICC(1) değerleri (Bliese, 2000; LeBreton ve Senter, 2008), .40 ve üzeri ICC(2) değer- 
Tablo 1. Araştırmanın Değişkenlerine Ait Ortalama, Standart Sapma ve Korelasyon Değerleri ile Ayrışma Geçerliği için Fornell ve Larcker Kriteri Analiz Sonuçları

\begin{tabular}{|c|c|c|c|c|}
\hline Değişkenler & $\begin{array}{c}\text { Takım Arkadaşı İşlem } \\
\text { Adaleti }\end{array}$ & $\begin{array}{l}\text { Takım Görev } \\
\text { Performans1 }\end{array}$ & $\begin{array}{c}\text { Takım } \\
\text { Kolektivizmi İnancı }\end{array}$ & $\begin{array}{c}\text { Takım Vatandaşlık } \\
\text { Davranışı }\end{array}$ \\
\hline Takım Arkadaşı İşlem Adaleti & $(0.87)$ & & & \\
\hline Takım Görev Performansı & $0.48 * *$ & $(0.72)$ & & \\
\hline Takım Kolektivizmi İnancı & $0.50 * *$ & $0.45^{* *}$ & $(0.78)$ & \\
\hline Takım Vatandaşlık Davranışı & $0.75 * *$ & $0.49 * *$ & $0.57 * *$ & $(0.88)$ \\
\hline Ort. & 4.00 & 4.12 & 4.11 & 3.90 \\
\hline$S$ & 0.44 & 0.42 & 0.35 & 0.47 \\
\hline
\end{tabular}

Not $1 .{ }^{*} p<.01$ düzeyinde anlaml1.

Not 2. Parantez içindeki değerler AVE karekökünü ifade etmektedir.

leri (Fleiss, 1986) verinin kümeleme için uygun olduğunu göstermektedir. Bu çalışmada, elde edilen ICC(1) ve ICC(2) değerleri sırasıyla, takım arkadaşı işlem adaleti için .14 ve $.50(F=1.98$ ve $p<.001)$, takım kolektivizmi inancı için .10 ve $.40(F=1.67, p<.001)$, takım vatandaşlık davranışı için .18 ve .57 'dir $(\mathrm{F}=2.32, p<.001)$. Böylece her takımın aritmetik ortalaması alınarak veriler kümelenmiş ve bu ortalamalar gözlenen değişkenler olarak işlem görmüşlerdir. $\mathrm{R}_{\mathrm{wg}(\mathrm{j}) \text {. }} \mathrm{ICC}(1)$ ve $\mathrm{ICC}(2)$ değerleri Biemann, Cole ve Voelpel (2012) tarafından geliştirilen araç ile hesaplanmıştır.

Ölçek Geçerliği ve Güvenirliği. Bu çalışmada tüm değişkenler için reflektif ölçekler kullanılmıştır (Chin, 1998). Ölçüm araçlarının psikometrik özelliklerini test etmek için, Kleijnen, Ruyter ve Wetzels'in (2007) uyguladıkları işleme paralel bir şekilde herhangi bir yapısal ilişkinin olmadığı boş (null) bir model hesaplanmıştır. İç tutarlılık güvenirliği ölçümünde PLS-YEM ile bileşik ölçek güvenirliği (CR) kullanılması önerilmektedir (Chin, 1998; Fornell ve Larcker, 1981). Bu nedenle, bu çalışmada güvenirliğin hesaplanmasında CR kullanılmıştır. CR değerinin .70 ya da daha yüksek olması yeterli bir bileşik ölçek güvenirliği olduğunu kanıtlamakla birlikte (Bagozzi ve Yi, 1988), .95'i geçmemesi gerekmektedir (Hair, Hult, Ringle ve Sarstedt, 2013). Bu çalışmada, takım kolektivizmi inancı, takım arkadaşı işlem adaleti, takım vatandaşlık davranışı ve takım görev performansı için CR değerleri sırasıyla, .90, .93, .95 ve .89'dur.

Daha sonra, ölçek maddelerinin bağlı oldukları faktörlere istatistiksel olarak anlamlı ve güçlü bir şekilde yüklenip yüklenmediğini gösteren birleşen geçerliği incelenmiştir. Çıkarılan ortalama varyans (AVE), birleşen geçerliğini değerlendirmede kullanılmaktadır (Fornell ve Larcker, 1981). AVE değeri için eşik değer .50'dir (Bagozzi ve Yi, 1988). Elde edilen bulgular neticesinde AVE değerleri takım kolektivizmi inancı, takım arkadaşı işlem adaleti, takım vatandaşlık davranışı ve takım görev performansı için sırasıyla, .61, .75, .77 ve .51'dir. Daha sonra, araştırmada kullanılan ölçeklerin ayırt edici geçerliği hesaplanmıştır. Ayırt edici geçerliğini değerlendirmede Fornell-Larcker (1981) kriteri yaygın olarak kullanılmaktadır. Bu kritere göre her değişkenin AVE karekökünün, değişkenlerin korelasyon katsayılarından büyük olması gerekmektedir. Tablo 1'de AVE kareköklerinin değişkenlerin korelasyon katsayılarından büyük olduğu ve dolayısıyla ayırt edici geçerliğini sağladığ1 görülmektedir.

\section{Bulgular}

Çalışmaya konu olan değişkenlere ait ortalamalar, standart sapma değerleri, korelasyon katsayıları Tablo 1 'de gösterilmektedir. PLS modeli uyum endekslerini sağlamamaktadır (Fornell ve Bookstein, 1982). PLS tekniğinde içsel değişkenleri belirleme katsayısı $\mathrm{R}^{2}$ (Chin, 1998) ve uyum iyiliği endeksi (GoF) model uyumunu değerlendirmede kullanılmaktadır (Tenenhaus ve ark., 2005). $\mathrm{R}^{2}$ etki çapı küçük $\left(.02 \leq R^{2}<.13\right)$, orta $\left(.13 \leq R^{2}\right.$ $<.26)$ ve büyük $\left(.26 \leq R^{2}\right)$ olarak sınıflandirılmaktadır (Cohen, 1988). Bu çalışmada, takım kolektivizmi inan- 


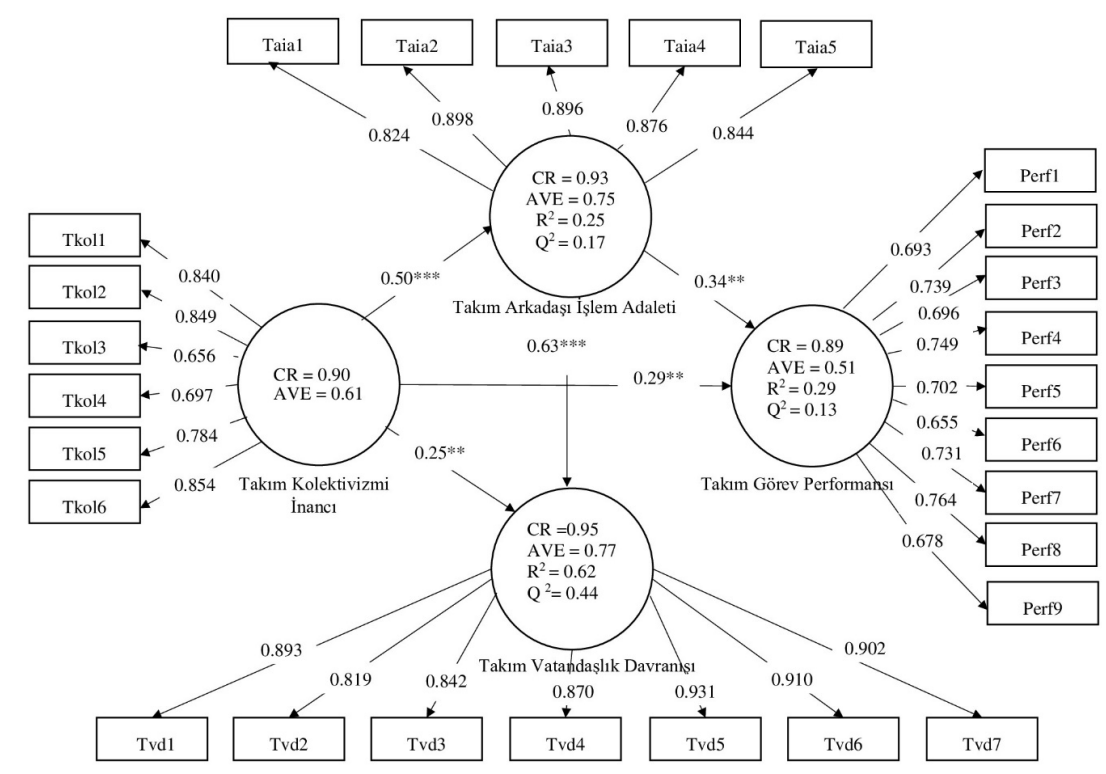

Not $1 .{ }^{* *} p<.01, * * * p<.001$

Not 2. GoF (modelin uyum iyiliği) $=.51$

Not 3. $\mathrm{CR}=$ Bileşik Güvenirlik (Composite Reliability), AVE = Çıkartılan Ortalama Varyans (Average Variance

Extracted), Q2 = Kestirimsel Uygunluk (Predictive Relevance).

Şekil 2. Yapısal Model ve Yol Katsayıları

c1, takım arkadaşı işlem adaleti üzerindeki değişimin \%25'ini açıklamaktadır. Takım kolektivizmi inancı ve takım arkadaşı işlem adaleti, takım görev performansı üzerindeki değişimin \%29'unu, takım vatandaşlık davranış1 üzerindeki değişimin \%62'sini açıklamaktadır. Buna göre, takım kolektivizmi inancının işlem adaleti üzerindeki etki çapı ortayken, takım görev performansı ve takım vatandaşlık davranıșı üzerindeki etki çapı büyüktür. PLS modelinin küresel geçerlik düzeyini belirlemekte kullanılan GoF ise dış ölçüm modelinin ortak varyans ortalaması ile tüm içsel değişkenlerin $\mathrm{R}^{2}$ ortalamasının çarpımının geometrik ortalaması ile bulunmaktadır. Küçük, orta ve geniş GoF etki çapları sırasıyla, $(.1 \leq G o F$ $<.25),(.25 \leq G o F<.36),(.36 \leq G o F)$ 'dur (Wetzels, Odekerken-Schröder ve Van Oppen, 2009). Bu araştırma modeli için hesaplanan etki çap1 .51 olarak bulunmuştur, dolayısıyla bu araştırma modelinin küresel geçerlik düzeyi geniş çaplıdır.

Ek olarak, Stone-Geisser $\mathrm{Q}^{2}$ istatistiğinin diğer bir ifadeyle kestirimsel uygunluğun $\left(\mathrm{Q}^{2}\right)$ değerlendirilmesi içsel değişkenlerin doğru tahmin edilip edilmediğini kontrol edebilmek için kullanılmaktadır (Geisser, 1974; Stone, 1974). Bu nedenle SmartPLS'deki körleme işlemiyle kestirimsel uygunluk belirlenmiştir. Chin'e (1998) göre $\mathrm{Q}^{2}$ değeri 0'dan büyükse araştırma modeli iyi bir tahmini açıklayıcılık düzeyine sahiptir. Bu yaklaşıma göre yapısal modelde takım arkadaşı işlem adaleti, takım görev performansı ve takım vatandaşlık davranışı için elde edilen $\mathrm{Q}^{2}$ değerleri sırasıyla .17, .13 ve .44 olmakla beraber, araştırma modelinin iyi bir açıklayıcılık düzeyine sahip olduğunu kanıtlamaktadır.

Araştırmaya dair yapısal model ve yol katsayıları Şekil 2'de gösterilmektedir. Araştırma bulguları, takım kolektivizmi inancı takım arkadaşı işlem adaletini istatistiksel açıdan pozitif yönde yordamakta olduğunu göstermekte $(\beta=.50, t=6.93, p<.001)$ ve $\mathrm{H}_{1}$ hipotezi desteklenmektedir. Takım kolektivizmi inancı, takım vatandaşlık davranışını yine istatistiksel açıdan pozitif yönde yordamaktadır $(\beta=.25, t=3.11, p=.002)$ ve $\mathrm{H}_{2}$ hipotezi desteklenmektedir. Takım kolektivizmi inanc1, takım görev performansını pozitif yönde yordamaktadır $(\beta=$ $.29, t=2.69, p=.009)$ ve $\mathrm{H}_{3}$ hipotezi desteklenmektedir. Takım arkadaşı işlem adaleti, takım görev performansını istatistiksel olarak pozitif yönde yordamaktadır $(\beta=.34$, $t=3.02, p=.003$ ) ve $\mathrm{H}_{4}$ hipotezi desteklenmektedir. Takım arkadaşı işlem adaleti, takım vatandaşlık davranışını istatistiksel olarak pozitif yönde yordamaktadır $(\beta=.63$, $t=8.72, p<.001$ ) ve böylece $\mathrm{H}_{5}$ hipotezinin de desteklendiği görülmektedir.

Araştırmada takım arkadaşı işlem adaletinin etkisini daha iyi anlayabilmek için takım kolektivizmi inancı ve takım vatandaşlık davranışı arasındaki ilişkide 


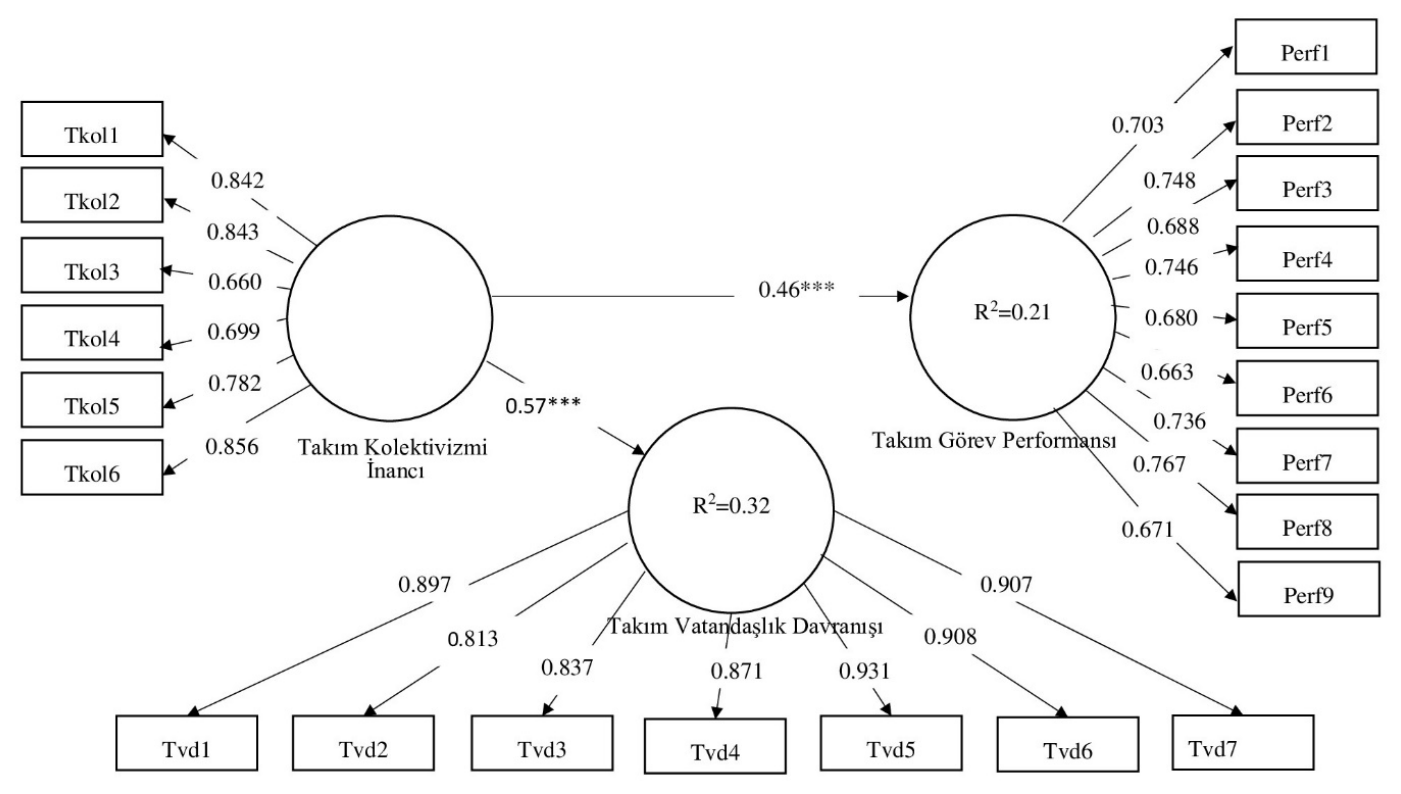

Not. $* * * p<.001$

Şekil 3. Aracı Değişkensiz Doğrudan Etki Modeli

ve ayrıca takım kolektivizmi inancı ve takım görev performansı arasındaki ilişkide takım arkadaşı işlem adaletinin aracı etkisi incelenmiştir. Aracı etkiyi ölçmek için yaygın olarak kullanılan Sobel testi, küçük örnekleme uygulandığında istatistiksel ölçme gücü az olduğundan ve normal dağılım gerektirdiğinden parametrik olmayan PLS-YEM yöntemiyle tutarlılık sağlayamamaktadır. Bu nedenle aracı etkiyi test etmek için PLS-YEM kapsaminda uygulanamayan sobel testi yerine bootstrapping işlemi kullanılmaktadır (Hair, Hult, Ringle ve Sarstedt, 2017; Henseler, Ringle ve Sinkovics, 2009; Klarner, Sarstedt, Hoeck ve Ringle, 2013; Sattler, Völckner, Riediger ve Ringle, 2010). Bu araştırmaları izleyerek çalışmada öncelikle SmartPLS içindeki bootstrapping işlemi kullanılarak aracı değişken olan takım arkadaşı işlem adaleti olmadan doğrudan etkinin anlamlılık düzeyine bakılmıştır. Daha sonra aracı değişken olan takım arkadaşı işlem adaleti modele dâhil edilerek yol katsayıları ve ilgili $t$ değerleri ile dolaylı etkinin anlamlılık düzeyi incelenmiştir. Modelde anlamlı düzeyde dolaylı etki mevcut değilse, aracı etki yok demektir. Anlamlı dolaylı etkinin olması aracının boyutunu belirlemek için esastır. Aracı değişken olmadan doğrudan etki modeli Şekil 3'te gösterilmiştir.

Tablo 2'de de ifade edildiği üzere aracı değişken ile olan dolaylı etki istatistiksel olarak anlamlı düzeydedir. Takım kolektivizmi inancı ile takım görev performansı arasında anlamlı bir doğrusal ilişkinin olduğu ve aracı değişkenin modele dâhil edilmesiyle yol katsayıs1$\operatorname{nın} \beta=.46$ 'dan $(p<.001), \beta=.29$ 'e $(p=0.009)$ düştüğü görülmektedir. Bununla birlikte aradaki ilişkiyi açıklama oran1 $R^{2}=.21$ 'den $R^{2}=.29$ 'e yükselmiştir. Ayrıca takım kolektivizmi inancı ile takım vatandaşlık davranışı arasında anlamlı bir doğrusal ilişkinin olduğu ve aracı değişkenin modele dâhil edilmesiyle yol katsayısının $\beta$ $=.57$ 'den $(p<.001) \beta=.25$ 'e $(p=0.002)$ düştüğü görülmektedir. Ancak aradaki ilişkiyi açıklama oranı $R^{2}=$ .32 'den $R^{2}=.62$ 'ya yükselmiştir. Böylece takım arkadaşı işlem adaletinin kısmi aracılık rolü olduğu söylenebilir.

Ek olarak, aracı etkinin gücünü incelemek için toplam etki ve varyansın nedeni (VAF) değerleri kullanılmaktadır (Wong, 2016). Toplam etki, doğrudan etki ve dolaylı etkinin toplanması ile bulunur. $\mathrm{H}_{6}$ ' da toplam etki $=.25+.31=.56$ ve $\mathrm{H}_{7}{ }^{\prime}$ de toplam etki $=.29+.17$ $=.46$ ' dir. VAF değeri dolaylı etki/toplam etki formülü ile hesaplanmaktadır. VAF değeri için eşik değer .20'dir ve .20 altındaki değerler aracı etkinin olmadığını göstermektedir. .20 ile .80 arasındaki değerler kısmi aracı etkiyi, .80 ve üzeri ise tam aracı etkiyi göstermektedir (Hair ve ark., 2013). $\mathrm{H}_{6}$ için VAF değeri $=.31 / .56=.55$ ve $\mathrm{H}_{7}$ için VAF değeri $=.17 / .46=.37$ olarak hesaplanmıştır. Bu araştırmada Tablo 2'de gösterildiği üzere takım kolektivizmi inancının takım vatandaşlık davranışı üzerindeki etkisinin \%55'i aracı değişken olan takım arkadaşı işlem adaleti ile açıklanmaktadır ve aracının boyutu k1smi olarak kabul edilmektedir. Böylece $\mathrm{H}_{6}$ hipotezi 
Tablo 2. Aracı Etkiye Ait PLS-YEM Analiz Sonuçları

\begin{tabular}{|c|c|c|c|c|c|c|c|c|c|}
\hline 芧 & İşlem & Yol & $\begin{array}{l}\text { Yol } \\
\text { Katsayıs1 }\end{array}$ & $\begin{array}{l}\text { Arac1 } \\
\text { Etkisi }\end{array}$ & S & $\begin{array}{l}\text { Toplam } \\
\text { Etki }\end{array}$ & VAF & $\begin{array}{l}t \\
\text { Değeri }\end{array}$ & Sonuç \\
\hline \multirow[b]{2}{*}{$\mathrm{H}_{6}$} & $\begin{array}{l}\text { Aracısız } \\
\text { Doğrudan Etki }\end{array}$ & $\mathrm{TKI} \rightarrow \mathrm{TVD}$ & $.57 * * *$ & $g / d$ & $\mathrm{~g} / \mathrm{d}$ & $\mathrm{g} / \mathrm{d}$ & $g / d$ & 7.81 & \multirow[b]{2}{*}{$\begin{array}{l}\text { Kismen } \\
\text { Desteklendi }\end{array}$} \\
\hline & $\begin{array}{l}\text { Aracı ile } \\
\text { Dolaylı Etki }\end{array}$ & $\begin{array}{l}\text { TKİ } \rightarrow \text { TVD } \\
\text { TKİ } \rightarrow \text { TAİA } \\
\text { TAİA } \rightarrow \text { TVD }\end{array}$ & $\begin{array}{l}.25 * * \\
.50 * * * \\
.63 * * *\end{array}$ & $.31 * * *$ & 0.059 & 0.56 & $\% 55$ & 5.17 & \\
\hline \multirow[b]{2}{*}{$\mathrm{H}_{7}$} & $\begin{array}{l}\text { Aracısız } \\
\text { Doğrudan Etki }\end{array}$ & $\mathrm{TKI} \rightarrow \mathrm{TGP}$ & $.46 * * *$ & $g / d$ & $\mathrm{~g} / \mathrm{d}$ & $\mathrm{g} / \mathrm{d}$ & $g / d$ & 6.27 & \multirow[b]{2}{*}{$\begin{array}{l}\text { Kismen } \\
\text { Desteklendi }\end{array}$} \\
\hline & $\begin{array}{l}\text { Aracı ile } \\
\text { Dolaylı Etki }\end{array}$ & $\begin{array}{l}\mathrm{TKI} \rightarrow \mathrm{TGP} \\
\mathrm{TKI} \rightarrow \mathrm{TAI} A \\
\mathrm{TAI} \dot{I} \mathrm{~A} \rightarrow \mathrm{TGP}\end{array}$ & $\begin{array}{l}.29 * * \\
.50 * * * \\
.34 * *\end{array}$ & $.17 * *$ & 0.060 & 0.46 & $\% 37$ & 2.87 & \\
\hline
\end{tabular}

Not 1. $N=93$.

Not $2 .{ }^{*} p<.01, * * * p<.001$ düzeyinde anlaml.

Not 3. TKİ: Takım Kolektivizmi İnancı, TVD: Takım Vatandaşlık Davranışı, TAİA: Takım Arkadaşı İşlem Adaleti, TGP: Takım Görev Performansı, g/d: geçerli değil.

kısmen desteklenmektedir. Takım kolektivizmi inancının takım görev performansı üzerindeki etkisinin \%37'si aracı değişken takım arkadaşı işlem adaleti ile açıklanmaktadır ve aracının boyutu kısmi olarak kabul edilmektedir. Dolayısı ile $\mathrm{H}_{7}$ hipotezi de kısmen desteklenmektedir.

\section{Tartışma ve Sonuç}

$\mathrm{Bu}$ araștırmanın amacı takım kolektivizmi inancının, takım vatandaşlık davranışı ve takım görev performansı üzerindeki yordayıcı etkilerini test etmek ve ayrıca takım arkadaşı adaletinin aracılık etkisinin bulunup bulunmadığını incelemektir. Elde edilen bulgular, takım kolektivizmi inancının takım arkadaşı adaleti, takım vatandaşlık davranışı ve takım görev performansı üzerinde pozitif yönde yordayıcı etkisinin olduğunu ayrıca takım arkadaşı işlem adaletinin, takım kolektivizmi inancı, takım vatandaşlık davranışı ve takım görev performansı arasındaki ilişki üzerinde kısmi aracılık rolü olduğunu göstermektedir.

Araştırmanın sonuçları, toplulukçuluk hakkındaki alanyazın ile paralellik göstermektedir. Önceki çalışmalarda (örn., Colquitt ve ark., 2002; Dayan ve Çolak, 2008) takım kolektivizmi inancının işlem adaleti iklimi ile pozitif bir ilișkisinin olduğu bulunmuştur. Bu çalışmada da takım düzeyinde toplulukçuluğun takım arkadaşı kaynaklı işlem adaleti algıları ile pozitif bir ilişkisinin olduğu tespit edilmiştir. Takım kolektivizmi inancının, takım vatandaşlık davranışı üzerinde pozitif etkisinin olduğuna dair elde edilen bulgu, bireysel analiz düzeyinde yapılan önceki çalışmaların bulguları ile benzerlik göstermektedir (Finkelstein, 2012, 2014; Jackson ve ark., 2006; Van Dyne ve ark., 2000). Aynı zamanda takım kolektivizmi inancının takım görev performansı (Bell, 2007; Eby ve Dobbins, 1997) üzerine etkisinin olduğunu kanitlayan çalışmalar ile de tutarlılık göstermektedir.

Takım arkadaşları ile ilgili olarak takım düzeyinde değerlendirilen işlem adaletinin yazında bahsedildiği gibi takım görev çalışma süreci aracılığıyla takım vatandaşlık davranışını ve takım performansını etkilediği bulunmuştur (Cropanzano ve ark., 2011). Gerçekleştirilen diğer bir çalışmada ise takım arkadaşı işlem adaletinin kişilerarası takım davranışı aracılığıyla takım vatandaşlık davranışını etkilediği ancak takım görev davranışı aracılığıyla takım görev performansını etkilemediği görülmüştür (Neumann, 2011). Li ve arkadaşları (2013) yaptıkları çalışmada, takım arkadaşı adaletinin iş birlikçi takım çalışması süreci aracılığıyla takım performansına etkisinin olmadığını bulmuştur. Bu üç çalışmada elde edilen sonuçların farklılık göstermesi, takımın bireyci ya da toplulukçuluk eğilimli üyelerden oluşmasından kaynaklanıyor olabilir. Takım görev çalışması bir zorunluluktan ziyade görev performansını başarıyla yerine getirebilmek amaciyla ek çaba ortaya koyma ve takıma adanmışlı̆̆ gösteren faaliyetler şeklinde tanımlanmaktadır (Hohenstein, 2007). Toplulukçular, takımın çıkarları ve başarısı için çaba göstermeye kendinden güdümlü (Chen, Sharma, Edinger, Shapiro ve Farh, 2011) ve adil 
işlemlere karşı duyarlı bireyler (Lind ve Tyler, 1988; Moorman ve Blakey, 1995) oldukları için doğal olarak takım görev davranışlarını bireyci üyelere göre daha fazla yerine getirmektedirler. Bu durum da takımın görev performansına ve takım vatandaşlık davranışına pozitif bir şekilde yansımaktadır. Adalet algıları bireylerin sonuçlardan ya da işlemlerden ne beklediğine bağlı olarak şekillenebilmektedir (Cropanzano ve Ambrose, 2001). Eğer bir işlem bireycilerin kişisel çıkarlarına katkı sağlıyorsa bu bireyciler tarafindan daha adil olarak algılanacaktır. Bireyciler her seferinde "bunun bana bir yararı var mi?" sorusunu sormaktadırlar (Triandis, 1990). Bu nedenden dolayı bireyci takım üyeleri için adalet algıları, takımın çıkarları için daha fazla çaba göstermelerini sağlamayabilir. Buradan hareketle takım görev çalışması içerisindeki bireycilerin ișlem adaletine karşı toplulukçular kadar duyarlı olmadığı sonucu ortaya çıkmaktadır. Kişilerarası takım çalışması davranışı ise takımın kolektif hedefleri yerine getirmek için görev çalışmasını destekleyen bilişsel, sözel ve davranışsal faaliyetler aracılığıyla girdileri çıktılara dönüştüren ve karşılıklı çalışmaları ifade eden bir süreç şeklinde tanımlanmaktadır (Marks ve ark., 2001). Diğer bir söyleyişle, kişilerarası takım çalışması takım üyelerinin birbirlerine destek olmasını ve iş birliği yapmasını ifade etmektedir (Hohenstein, 2007). Bu anlamda toplulukçu bireyler takımın başarılı olmasını sağlamak için takım üyelerine yardım edip onlarla iş birliği yaparak kişilerarası takım çalışmas1 davranış1 göstermektedirler (Taras, Kirkman ve Steel, 2010; Welbourne, Johnson ve Erez, 1998). Bireyciler, takım çalışmasına uygun kişiler değildirler. Buna rağmen kendi çıkarlarına faydalı bir durumun söz konusu olması halinde işlemleri adil olarak algılayarak kişilerarası takım çalışmasına katkı sağlayabilmektedirler. Bu bilgiler 1şığıında takım arkadaşı işlem adaletinin, takım görev çalışması süreci ve kişilerarası takım çalışması süreci aracılığıyla takım görev performansı ve takım vatandaşlık davranışı üzerinde istatistiki açıdan bir etkisinin olup olmayacağının takım üyelerinin toplulukçu ya da bireyci olup olmamalarına göre şekilleneceği düşünülmektedir.

\section{Çalışmanın İlgili Yazına Potansiyel Katkısı}

$\mathrm{Bu}$ araştırma, takım arkadaşı işlem adaletinin takım kolektivizmi inancı ve takım vatandaşlık davranışı ile takım görev performansı arasındaki ilişkide aracılık etkisini inceleyen ilk çalışma olması nedeniyle orijinal bir nitelik taşımaktadır. Bu özelliğe ek olarak konuyla ilgili alanyazında yapılan araştırmalarda takım kolektivizmi inancının takım arkadaşı işlem adaleti üzerine etkisini inceleyen başka bir çalışmanın henüz gerçekleştirilmemiş olduğu da tespit edilmiştir.

Bugüne kadar yapılmış olan çalışmalarda toplulukçuluğun takım vatandaşlık davranışına olan etkisi araş- tırılmış olsa da bu çalışmalarda toplulukçuluk bireysel düzeyde incelenmiştir. Toplulukçuluğu takım yapısında kavramsallaştırarak takım vatandaşlık davranışını etkileyip etkilemediğini inceleyen bir çalışma konuyla ilgilenen araştırmacılar tarafindan henüz gerçekleştirilmemiştir. Ehrhart'ın (2004) belirtmiş olduğu gibi takım vatandaşlık davranışı bireysel düzeydeki örgütsel vatandaşlık davranışı öncülleriyle tam anlamıyla açıklanamadığından dolayı bu çalışmada toplulukçuluk takım düzeyinde bir değişken olarak ele alınmıştır. Sonuç olarak takım kolektivizmi inancının takım vatandaşlık davranışına dair istatistiki açıdan pozitif etkilerinin olduğu gözlemlenmiştir. $\mathrm{Bu}$ araştırmayla birlikte yukarıda da ifade edildiği üzere alanyazındaki boşluğa önemli bir katkıda bulunulduğu düşünülmektedir.

Takım arkadaşı adaleti üzerine Cropanzano ve arkadaşları (2011) ile Li ve arkadaşları (2013) tarafından gerçekleştirilen ilk görgül çalışmaların örneklemini üniversite ögrrencileri oluşturmuştur. Bu sebepten dolayı elde edilen sonuçlar, iş yaşamına dair bir genelleme yapılabilmesi için yeterli değildir. $\mathrm{Bu}$ araştırmada gözlemlenen bulgular iş yaşamının içerisinde yer alan ve fiili olarak takımlarda çalışan kişilerden elde edildiğinden dolayı iş ortamının doğal sonuçlarını yansıttığı düşünülmektedir. Başka bir ifadeyle, gerçek bir iş ortamında toplulukçu bireylerden oluşan takımlarda, takım üyelerinin işlem adaleti algıları aracılığ performansına ve takım vatandaşlık davranışına dair etkilerinin istatistiksel açıdan anlamlı sonuçlarının olduğu görülmektedir.

Yazında ifade edilenlere ek olarak takım arkadaşı işlem adaleti, takım vatandaşlık davranışı ve takım kolektivizmi inancı gibi kavramlar daha önce Türkiye'de bu türde herhangi bir çalışmada ele alınmadığından dolayı, ortaya konulan bu çalışma aracılığıyla bu kavramların Türkiye yazınına girmesine öncülük edeceği düşünülmektedir. Bununla birlikte takım arkadaşı adaletinin yeni bir kavram olması sebebiyle dünya yazınına Türkiye örneklemiyle yapılmış bir çalışma olarak da ek bir katkı sağlayabileceği düşünülmektedir.

\section{Çalıșmanın Uygulamaya Katkısı}

$\mathrm{Bu}$ araştırmanın uygulamaya bazı katkıları söz konusudur. İlk olarak takım kolektivizmi inancının takım performansını pozitif yönde yordadığı tespit edilmiştir. Toplulukçu bireyler, takım çalışmalarına daha iyi uyum göstermekte ve başarılı olmaktadırlar. Kendi çıkarlarını takım çıkarlarının önünde tutan bireyci çalışanların takım içerisindeki diğer kişilerle nasıl etkin bir şekilde çaliştırabilineceğinin belirlenebilmesi oldukça güç bir iştir. Buna rağmen dikkatli bir planlama ve öngörüyle bireyler başarılı takım çalışanları haline getirilebilirler. Takım hedefi ile bireysel hedefi aynı doğrultuda birleştirmek 
ve takım için sarf edilen bireysel katkıyı ödüllendirmek de takım çalışmasının gerçekleştirilmesine olanak sağlayabilir ve böylece üretkenlik kayıplarının önüne geçilebilir (Erez ve Somech, 1996; Gundlach ve ark., 2006). $\mathrm{Bu}$ bağlamda, personel seçmede takım değerleri ile kişi uyumuna dikkat etmenin ve buna göre planlamalar yapmanın işletmelere yarar sağlayabileceği göz önünde bulundurulmalıdır. Bu durumun işten ayrılma niyetinde azalma, yüksek iş tatmini ve performans gibi işle ilgili olumlu sonuçların elde edilmesine katkıda bulunabileceği düşünülmektedir.

Ayrıca iş yerinde adaletin değerli olduğunu savunan araştırmacılara göre eğer çalışanlar kendilerine adil bir şekilde davranıldığına inanırlarsa, iş çıktılarına ve görevlerine karşı daha olumlu davranışlar sergilemektedirler (Moorman, 1991). Greenberg'e (2005) göre kendilerine adil davranıldığını düşünen kişiler daha üretken olmakta ve yüksek performans göstermektedirler. Takım kolektivizmi inancı, takım içerisinde işlem adaleti algılarını olumlu yönde etkileyen bir kavramdır. Takım kolektivizmi inancının düșük olması halinde takım içerisinde oluşabilecek adaletsizlik algısı, bireylerin işten ayrılma oranlarının artması ve performanslarının düşmesi gibi örgüt başarısını olumsuz etkileyen durumların ortaya çıkmasına neden olabilmektedir. Böyle durumlarda işletmeler, takım çalışanlarının bağlılıklarını artırmak ve görev performanslarını tam olarak yerine getirmelerini sağlamak amacıyla takım içerisindeki işlem adaletini desteklemelerinin önemli olduğunu göz önünde bulundurmalıdırlar. Çalışanlara adil olmanın öğretilmesi bu doğrultuda izlenecek yöntemlerden biridir. Böylece çalışanlar olumsuz davranmaya daha az eğilimli olmakla birlikte takımdaki diğer kişilere yardım etmeye ve daha fazla çalışmaya da eğilim gösterebilmektedirler (Greenberg, 2005). Buna ek olarak, özellikle yüksek işlem adaleti algısı, güç kullanımının istismarını önlemeye yönelik bir mekanizma oluşturduğundan dolayı takım üyelerinin korkusuzca bilgi paylaşabileceği güvenli bir psikolojik ortam yaratılmış olmaktadır (Lind ve Earley, 1992). Bu durum, takım üyelerinin takımdaki diğer arkadaşlarıyla birlikte daha eş güdümlü bir şekilde çalışmalarına ve takım performansına daha fazla katkıda bulunmalarına neden olacaktır.

\section{Çalışmanın Kısıtları ve Öneriler}

$\mathrm{Bu}$ çalışmanın başlıca kısıtlarından biri kesitsel bir çalışma olmasıdır. Bu sebeple nedenselliği incelemek mümkün olmamaktadır. Nedensel ilişkileri daha kesin test edebilmek için boylamsal çalışma yapılması gerekmektedir (Colquitt ve ark., 2002; Ehrhart, 2004; Molina ve ark., 2015). Diğer bir kısıt ise görev performansının değerlendirilmesidir. Bir kısım araştırmacı performansin sadece amir tarafından değerlendirmesini önerirken (örn., Colquitt ve ark., 2002) bir kısım araştırmacı da amirin takım üyeleri ile olan ilişkisinin performans değerlendirme sonuçlarını etkileyebileceğini düşünmektedir (Cropanzano ve ark., 2011; Gürbüz ve Ayhan, 2017). $\mathrm{Bu}$ nedenle amir ile birlikte takım üyelerinin de içerisinde yer aldıkları takıma dair görev performansının değerlendirilmesi ve elde edilen verilerin ortalamasının alınması önerilmektedir (Gürbüz ve Ayhan, 2017). Ancak gelecekte yapılacak çalışmalarda iki amirin birbirinden bağımsız olarak takım performansını değerlendirmesinin oyların güvenirliğini ölçebilmek açısından daha doğru bir yöntem olacağı (Cropanzano ve ark., 2011) dolay1sıyla da bu kısıtı gidereceği düşünülmektedir.

Takım arkadaşı adaleti kavramı henüz yeni bir kavram olduğundan bu konu ile ilgili az sayıda çalışma ortaya konulmuştur. Ancak bu kavram gelecek çalışmalar için önemli bir potansiyele sahiptir. Şimdiye kadar yapılmış olan çalışmalarda takım arkadaşı adaleti kavramının, adalet ikliminin ötesinde çalışanlar üzerinde önemli etkileri olduğu gözlemlenmiştir. Ayrıca, çalışanların takım arkadaşı adaleti ve adalet ikliminin birbirinden farklı iki adalet kaynağı olduğunu ayırt edebildikleri yapılmış olan görgül çalışmalarla ortaya konulmuştur. Bu yüzden yapılacak olan araştırmalarda kişilerin sadece örgütsel otoriteyle ilgili adalet algılarının değil, takım ya da bölüm olarak çalışma arkadaşlarından dolayı algıladıklarının da bir adalet kaynağı olduğu göz önünde bulundurulmalıdır. Her yeni teorik kavramda olduğu gibi bu teorik kavramla da ilgili daha önceden yapılmış görgül çalışmaların az olması nedeniyle takım arkadaşı adaletinin potansiyel öncülleri ve sonuçlarının araştırılması büyümekte olan iş yeri adalet araştırmalarına katk1 sağlayacaktır. Takımlar için kritik öneme sahip olan takım bağlılığı ve güven gibi diğer adalet kaynakları ile ilişkisi meta-analiz çalışmalarıyla kanıtlanmış (Colquitt ve ark., 2001) kavramların, takım arkadaşı kaynaklı adalet ile ilişkilerinin de araştırılması önerilmektedir. Ayrıca takım düzeyindeki değişkenlerin (örn., takım arkadaşı adaleti) bireyin işten ayrılma niyeti, bireyin işe ilişkin algıladığı stres gibi bireysel düzeydeki değişkenlere olan etkisinin çapraz düzey olarak incelenmesinin alanyazına katkı sağlayacağı düşünülmektedir. Ek olarak, Gundlach ve arkadaşlarının (2006) da önerdiği gibi toplulukçuluğun takım performansı ve takım vatandaşlık davranışı üzerindeki etkisinin sosyal kimlik kuramı ve sosyal ilişkiler modeli aracılığg ile incelenmesinin faydalı olacağ düşünülmektedir. 


\section{Kaynaklar}

Ambrose, M. L. ve Schminke, M. (2009). The role of overall justice judgments in organizational justice research: A test of mediation. Journal of Applied Psychology, 94(2), 491-500.

Bagozzi, R. P. ve Yi, Y. (1988). On the evaluation of structural equation models. Journal of the Academy of Marketing Science, 16(1), 74-94.

Baker, D. P. ve Salas, E. (1997). Principles for measuring teamwork: A summary and look toward the future. M. T. Brannick, E. Salas ve C. Prince (Ed.), Team performance assessment and measurement: Theory, methods, and applications içinde (331-355). Mahwah, NJ: Erlbaum.

Ball, G. A., Trevino, L. K. ve Sims, H. P. (1994). Just and unjust punishment: Influences on subordinate performance and citizenship. Academy of Management Journal, 37(2), 299-322.

Bell, S. T. (2007). Deep-level composition variables as predictors of team performance: A meta-analysis. Journal of Applied Psychology, 92(3), 595-615.

Biemann, T., Cole, M. S. ve Voelpel, S. (2012). Within-group agreement: On the use (and misuse) of rWG and rWG $(\mathrm{J})$ in leadership researchand some best practice guidelines. The Leadership Quarterly, 23(1),66-80.

Bliese, P. D. (1998). Group size, ICC values, and group-level correlations: A simulation. Organizational Research Methods, 1(4), 355-373.

Bliese, P. D. (2000). Within-group agreement, non-independence, and reliability: Implications for data aggregation and analysis. K. J. Klein ve S. W. J. Kozlowski (Ed.), Multilevel theory, research, and methods in organizations: Foundations, extensions, and new directions (1. Baskl) içinde (349381). San Francisco, CA, US: Jossey-Bass.

Bond, M. H., Leung, K. ve Wan, K. C. (1982). How does cultural collectivism operate? The impact of task and maintenance contributions on reward distribution. Journal of Cross-Cultural Psychology, 13(2), 186-200.

Brislin, R. W. (1970). Back-translation for cross-cultural research. Journal of Cross-Cultural Psychology, l(3), 185-216.

Brockner, J. ve Wiesenfeld, B. M. (1996). An integrative framework for explaining reactions to decisions: interactive effects of outcomes and procedures. Psychological Bulletin, 120(2), 189-208.

Burke, K. ve Leben, S. (2007). Procedural fairness: A key ingredient in public satisfaction. Court Review, 44(1-2), 4-25.
Chen, G., Sharma, P. N., Edinger, S. K., Shapiro, D. L. ve Farh, J. L. (2011). Motivating and demotivating forces in teams: Cross-level influences of empowering leadership and relationship conflict. Journal of Applied Psychology, 96(3), 541.

Chin, W. W. (1998). The partial least squares approach to structural equation modeling. Modern Methods for Business Research, 295(2), 295-336.

Cohen, J. (1988). Statistical power analysis for the behavioral sciences. Hillsdale, NJ: Lawrence Earlbaum Associates.

Cole, M. S., Carter, M. Z. ve Zhang, Z. (2013). Leader-team congruence in power distance values and team effectiveness: The mediating role of procedural justice climate. Journal of Applied Psychology, 98(6), 962.

Colquitt, J. A. (2004). Does the justice of the one interact with the justice of the many? Reactions to procedural justice in teams. Journal of Applied Psychology, 89(4), 633.

Colquitt, J. A., Conlon, D. E., Wesson, M. J., Porter, C. O. ve Ng, K. Y. (2001). Justice at the millennium: a meta-analytic review of 25 years of organizational justice research. Journal of Applied Psychology, 86(3), 425-445.

Colquitt, J. A., Noe, R. A. ve Jackson, C. L. (2002). Justice in teams: Antecedents and consequences of procedural justice climate. Personnel Psychology, 55(1), 83-109.

Cropanzano, R. ve Ambrose, M. L. (2001). Procedural and distributive justice are more similar than you think: A monistic perspective and a research agenda. Greenberg J. ve Cropanzano, R. (Ed.), Advances in organization justice içinde (119-151). Stanford University Press.

Cropanzano, R. ve Greenberg, J. (1997). Progress in organizational justice: Tunneling through the maze. International Review of Industrial and Organizational Psychology, 12, 317-372.

Cropanzano, R. ve Mitchell, M. S. (2005). Social exchange theory: An interdisciplinary review. Journal of Management, 31(6), 874-900.

Cropanzano, R. ve Schminke, M. (2001). Using social justice to build effective work groups. M. E. Turner (Ed.), Groups at work: Theory and research içinde (143-171). Hilsdale, NJ: Erlbaum.

Cropanzano, R., Li, A. ve Benson III, L. (2011). Peer justice and teamwork process. Group \& Organization Management, 36(5), 567-596.

Dayan, M. ve Colak, M. (2008). The role of procedural justice in the new product development process. European Journal of Innovation Management, 11(2), 199-218. 
DeConinck, J. (2003). The impact of a corporate code of ethics and organizational justice on sales managers' ethical judgments and reaction to unethical behavior. Marketing Management Journal 13(1), 23-31.

Dietz, J., Robinson, S. L., Folger, R., Baron, R. A., ve Schulz, M. (2003). The impact of community violence and an organization's procedural justice climate on workplace aggression. Academy of $\mathrm{Ma}$ nagement Journal, 46(3), 317-326.

Drach-Zahavy, A. (2004). Exploring team support: The role of team's design, values, and leader's support. Group Dynamics: Theory, Research, and Practice, 8(4), 235-252.

Earley, P. C. (1989). Social loafing and collectivism: A comparison of the United States and the People's Republic of China. Administrative Science Quarterly, 34(4), 565-581.

Earley, P. C. (1993). East meets West meets Mideast: Further explorations of collectivistic and individualistic work groups. Academy of Management Journal, 36(2), 319-348.

Earley, P. C. (1994). Self or group? Cultural effects of training on self-efficacy and performance. Administrative Science Quarterly, 39(1) 89-117.

Earley, P. C. ve Gibson, C. B. (1998). Taking stock in our progress on individualism-collectivism: 100 years of solidarity and community. Journal of Management, 24(3), 265-304.

Eby, L. T. ve Dobbins, G. H. (1997). Collectivistic orientation in teams: An individual and group-level analysis. Journal of Organizational Behavior, 18(3), 275-295.

Ehrhart, M. G. (2004). Leadership and procedural justice climate as antecedents of unit-level organizational citizenship behavior. Personnel Psychology, 57(1), 61-94.

Ehrhart, M. G. ve Naumann, S. E. (2004). Organizational citizenship behavior in work groups: A group norms approach. Journal of Applied Psychology, 89(6), 960.

Ehrhart, M. G. Bliese, P. D. ve Thomas, J. L. (2006). Unit-level OCB and unit effectiveness: Examining the incremental effect of helping behavior. Human Performance, 19(2), 159-173.

Elovainio, M., van den Bos, K., Linna, A., Kivimäki, M., Ala-Mursula, L., Pentti, J. ve Vahtera, J. (2005). Combined effects of uncertainty and organizational justice on employee health: Testing the uncertainty management model of fairness judgments among Finnish public sector employees. Social Science \& Medicine, 61(12), 2501-2512.

Emuwa, A. (2013). Authentic leadership: Commitment to supervisor, follower empowerment, and procedural justice climate. Emerging Leadership Journeys, 6(1), 45-65.

Erdogan, B. ve Liden, R. C. (2006). Collectivism as a moderator of responses to organizational justice: Implications for leader-member exchange and ingratiation. Journal of Organizational Behavior, 27(1), 1-17.

Erez, M. ve Somech, A. (1996). Is group productivity loss the rule or the exception? Effects of culture and group-based motivation. Academy of Management Journal, 39(6), 1513-1537.

Finkelstein, M. A. (2012). Individualism/collectivism and organizational citizenship behavior: An integrative framework. Social Behavior and Personality: An International Journal, 40(10), 1633-1643.

Finkelstein, M. A. (2014). Individual differences in OCB: The contributions of organizational commitment and individualism/collectivism. International Journal of Psychology and Behavioral Sciences, 4(1), 1-8.

Fleiss, J.L. (1986). Reliability of measurement. The design and analysis of clinical experiments. John Wiley \& Sons: New York.

Fornell, C. ve Larcker, D. (1981). Evaluating structural equation models with unobservable variables and measurement error. Journal of Marketing Research, 18(1), 39-50.

Geisser, S. (1974). A predictive approach to the random effect model. Biometrika, 61(1), 101-107.

Goffnett, S. P. (2017). Leadership, goal acceptance, and QMS conformance readiness: Exploring the mediating effects of audit team cohesion. Total Quality Management \& Business Excellence, 42(9), 1-25.

Gomez-Mejia, L. R., ve Welbourne, T. (1991). Compensation strategies in a global context. People and Strategy, 14(1), 29-41.

Goodman, S. A. ve Svyantek, D. J. (1999). Person-organization fit and contextual performance: Do shared values matter. Journal of Vocational Behavior, 55(2), 254-275.

Greenberg, J. (2005). Managing behavior in organizations, (4. Baskl), Pearson Education, Inc. Published by Prentice Hall.

Gundlach, M., Zivnuska, S. ve Stoner, J. (2006). Understanding the relationship between individualism-collectivism and team performance through an integration of social identity theory and the social relations model. Human Relations, 59(12), 1603-1632.

Gümüşlüoğlu, L. ve Karakitapoğlu-Aygün, Z. (2010). Bilgi çalışanlarının adalet ve güçlendirme algılarının örgüte, lidere ve işe bağlılık üzerindeki etkileri. Türk Psikoloji Dergisi, 25(66), 21-36. 
Gürbüz, S. ve Ayhan, Ö. (2017). Lidere yakın olmanın dayanılmaz hafifliği: Lider-üye etkileşimi, görev performans1, tecrübe ve terfi edebilirlik arasındaki ilişkilerin testi. Türk Psikoloji Dergisi, 32(80), 1-19.

Hair Jr, J. F., Hult, G. T. M., Ringle, C. M. ve Sarstedt, M. (2013). A primer on partial least squares structural equation modeling (PLS-SEM). Thousand Oaks: Sage.

Hair Jr, J. F., Hult, G. T. M., Ringle, C. ve Sarstedt, M. (2017). A primer on partial least squares structural equation modeling (PLS-SEM)(2. Baskl), Sage Publications.

Henseler, J., Ringle, C. M. ve Sinkovics, R. R. (2009). The use of partial least squares path modeling in international marketing. Sinkovics, R. R. ve Ghauri, P. N. (Ed.), New challenges to international marketing (Advances in international marketing) içinde (277-319). Emerald Group Publishing Limited.

Henttonen, K., Janhonen, M. ve Johanson, J. E. (2013). Procedural justice climate in work teams: Antecedents and consequences. Academy of Management Proceedings, 2013(1), 13997. Briarcliff Manor, NY 10510: Academy of Management. https://doi.org/10.5465/ambpp.2013.13997abstract

Hoch, J. E. ve Kozlowski, S. W. (2014). Leading virtual teams: Hierarchical leadership, structural supports, and shared team leadership. Journal of Applied Psychology, 99(3), 390-403.

Hofstede G. (1980). Culture's consequences. Beverly Hills, CA Sage.

Hofstede, G. ve Bond, M. H. (1984). Hofstede's culture dimensions: An independent validation using Rokeach's value survey. Journal of Cross-Cultural Psychology, 15(4), 417-433.

Hohenstein, J. B. H. (2007). Does the bad outweigh the good? An examination of the effects of team member citizenship behavior and deviance on team performance. Yayınlanmamış doktora tezi, The Pennsylvania State University, Pennsylvania.

Jackson, C. L., Colquitt, J. A., Wesson, M. J. ve Zapata-Phelan, C. P. (2006). Psychological collectivism: A measurement validation and linkage to group member performance. Journal of Applied Psychology, 91(4), 884.

Jakopec, A., Sušanj, Z. ve Molina, A. (2015). Interactive effects of supervisory and peer justice climates on supervisory and peer-oriented outcomes.17th congress of the European Association of Work and Organizational Psychology: Respectful and effective leadership-managing people and organizations in turbulent times, Oslo, Norway.
James, L. R., Demaree, R. G. ve Wolf, G. (1984). Estimating within-group interrater reliability with and without response bias. Journal of Applied Psycho$\log y, 69(1), 85$.

Jordan, M. H., Feild, H. S. ve Armenakis, A. A. (2002). The relationship of group process variables and team performance: A team-level analysis in a field setting. Small Group Research, 33(1), 121-150.

Kenny, D. A. ve La Voie, L. (1985). Separating individual and group effects. Journal of Personality and Social Psychology, 48(2), 339-348.

Kirkman, B. L. ve Shapiro, D. L. (2001). The impact of team members' cultural values on productivity, cooperation, and empowerment in self-managing work teams. Journal of Cross-Cultural Psychology, 32(5), 597-617.

Klarner, P., Sarstedt, M., Hoeck, M. ve Ringle, C. M. (2013). Disentangling the effects of team competences, team adaptability, and client communication on the performance of management consulting teams. Long Range Planning, 46(3), 258-286.

Kleijnen, M., De Ruyter, K. ve Wetzels, M. (2007). An assessment of value creation in mobile service delivery and the moderating role of time consciousness. Journal of Retailing, 83(1), 33-46.

Konovsky, M. A. ve Pugh, S. D. (1994). Citizenship behavior and social exchange. Academy of Management Journal, 37(3), 656-669.

Korsgaard, M., Schweiger, D. ve Sapienza, H. (1995). Building commitment, attachment, and trust in strategic decision-making teams: The role of procedural justice. The Academy of Management Journal, 38(1), 60-84.

Kozlowski, S. W. J. ve Klein, K. J. (2000). A multilevel approach to theory and research in organizations: Contextual, temporal, and emergent processes. K. J. Klein ve S. W. J. Kozlowski (Ed.), Multilevel theory, research, and methods in organizations: Foundations, extensions, and new directionsiçinde (3-90). San Francisco, CA, US: Jossey-Bass.

Lai, J. Y., Lam, L. W. ve Lam, S. S. (2013). Organizational citizenship behavior in work groups: A team cultural perspective. Journal of Organizational Behavior, 34(7), 1039-1056.

LeBreton, J. M. ve Senter, J. L. (2008). Answers to 20 questions about interrater reliability and interrater agreement. Organizational Research Methods, 11(4), 815-852.

Leventhal, G. S. (1976). Fairness in social relationships. J.W. Thibaut, JT Spence ve RC Carson (Ed.),Contemporary topics in social psychologyiçinde (211239). Morristown. 
Li, A. ve Cropanzano, R. (2009). Fairness at the group level: Justice climate and intraunit justice climate. Journal of Management, 35(3), 564-599.

Li, A., Cropanzano, R. ve Bagger, J. (2013). Justice climate and peer justice climate: A closer look. Small Group Research, 44(5), 563-592.

Liden, R. C., Wayne, S. J., Jaworski, R. A. ve Bennett, N. (2004). Social loafing: A field investigation. Journal of Management, 30(2), 285-304.

Lind, E. A. ve Earley, P. C. (1992). Procedural justice and culture. International Journal of Psychology, 27(2), 227-242.

Lind, E. A. ve Tyler, T. R. (1988). The social psychology of procedural justice. Newyork: Plenum.

Marks, M. A., Mathieu, J. E. ve Zaccaro, S. J. (2001). A temporally based framework and taxonomy of team processes. Academy of Management Review, 26(3), 356-376.https://doi.org/10.5465/amr.2001.4845785

Markus, H. R. ve Kitayama, S. (1991). Culture and the self: Implications for cognition, emotion, and motivation. Psychological Review, 98(2), 224-253.

Mello, J.A. (2015). Strategic human resource management (4. Baskl). Cengage Learning.

Mitchell, R., Boyle, B. ve Von Stieglitz, S. (2018). Professional commitment and team effectiveness: A moderated mediation investigation of cognitive diversity and task conflict. Journal of Business and Psychology, 1-13. DOI: 10.1007/s10869-0189550-0.

Mitchell, R., Parker, V., Giles, M., Joyce, P. ve Chiang, V. (2012). Perceived value congruence and team innovation. Journal of Occupational and Organizational Psychology, 85(4), 626-648.

Molina, A., Jakopec, A., Cropanzano, R. ve Moliner, C. (2017). The role of peer justice climate. Moliner, C., Cropanzano, R., ve Martinez-Tur (Ed.), Organizational justice: International perspectives and conceptual advances (1. Baskl)içinde (87- 106). Routledge.

Molina, A., Moliner, C., Martínez-Tur, V., Cropanzano, R. ve Peiró, J. M. (2015). Unit-level fairness and quality within the health care industry: A justicequality model. European Journal of Work and Organizational Psychology, 24(4), 627-644.

Moorman, R. H. (1991). Relationship between organizational justice and organizational citizenship behaviors: Do fairness perceptions influence employee citizenship? Journal of Applied Psychology, 76(6), 845.

Moorman, R. ve Blakely, G. (1995). Individualism-collectivism as an individual difference predictor of organizational citizenship behavior. Journal of Organizational Behavior, 16(2), 127-142.
Moorman, R. H., Niehoff, B. P. ve Organ, D. W. (1993). Treating employees fairly and organizational citizenship behavior: Sorting the effects of job satisfaction, organizational commitment, and procedural justice. Employee Responsibilities and Rights Journal, 6(3), 209-225.

Morgeson, F. P. ve Hofmann, D. A. (1999). The structure and function of collective constructs: Implications for multilevel research and theory development. Academy of Management Review, 24(2), 249-265.

Mossholder, K. W., Bennett, N. ve Martin, C. L. (1998). A multilevel analysis of procedural justice context. Journal of Organizational Behavior, 19(2), 131141.

Murphy, C., Ramamoorthy, N., Flood, P. C. ve MacCurtain, S. (2006). Organizational justice perceptions and employee attitudes among Irish blue collar employees: An empirical test of the main and moderating roles of individualism/collectivism. $\mathrm{Ma}$ nagement Revue, 17(3), 328-343.

Naranjo-Gil, D., Hartmann, F. ve Maas, V. S. (2008). Top management team heterogeneity, strategic change and operational performance. British Journal of Management, 19(3), 222-234.

Naumann, S. E. ve Bennett, N. (2000). A case for procedural justice climate: Development and test of a multilevel model. Academy of Management Journal, 43(5), 881-889.

Naumann, S. E. ve Bennett, N. (2002). The effects of procedural justice climate on work group performance. Small Group Research, 33(3), 361-377.

Neumann, O. (2011). Peer justice in teams, antecedents and outcomes: Testing a structural equation model on data from the us self-storage industry Yayınlanmamış doktora tezi, University of Konstanz, Germany.

Niehoff, B. ve Moorman, R. (1993). Justice as a mediator of the relationship between methods of monitoring and organizational citizenship behavior. The Academy of Management Journal,36(3), 527-556.

O'Brien, R. M. (2007). A caution regarding rules of thumb for variance inflation factors. Quality $\& Q u$ antity, 41(5), 673-690.

Organ, D. W. (1988). A restatement of the satisfaction-performance hypothesis. Journal of Management, 14(4), 547-557.

Özbek, M. F., Yoldash, M. A. ve Tang, T. L. P. (2016). Theory of justice, OCB, and individualism: Kyrgyz citizens. Journal of Business Ethics, 137(2), 365-382.

Paine, J. B. ve Organ, D. W. (2000). The cultural matrix of organizational citizenship behavior: Some preliminary conceptual and empirical observations. $\mathrm{Hu}$ man Resource Management Review, 10(1), 45-59. 
Palanski, M. E., Kahai, S. S. ve Yammarino, F. J. (2011). Team virtues and performance: An examination of transparency, behavioral integrity, and trust. Journal of Business Ethics, 99(2), 201-216.

Parkes, L., Bochner, S. ve Schneider, S. (2001). Person-organisation fit across cultures: An empirical investigation of individualism and collectivism. Applied Psychology, 50(1), 81-108.

Pearce, C. L. ve Giacalone, R. A. (2003). Teams behaving badly: Factors associated with anti-citizenship behavior in teams. Journal of Applied Social Psychology, 33(1), 58-75.

Price, K. H., Harrison, D. A. ve Gavin, J. H. (2006). Withholding inputs in team contexts: Member composition, interaction processes, evaluation structure, and social loafing. Journal of Applied Psychology, 91(6), 1375.

Ramamoorthy, N. ve Flood, P. C. (2004). Individualism/ collectivism, perceived task interdependence and teamwork attitudes among Irish blue-collar employees: A test of the main and moderating effects? Human Relations, 57(3), 347-366.

Randel, A. E. (2003). The salience of culture in multinational teams and its relation to team citizenship behavior. International Journal of Cross Cultural Management, 3(1), 27-44.

Rhoades, L., Eisenberger, R. ve Armeli, S. (2001). Affective commitment to the organization: The contribution of perceived organizational support. Journal of Applied Psychology, 86(5), 825.

Sattler, H., Völckner, F., Riediger, C. ve Ringle, C. M. (2010). The impact of brand extension success drivers on brand extension price premiums. International Journal of Research in Marketing, 27(4), 319-328.

Shin, Y., Du, J. ve Choi, J. N. (2015). Multi-level longitudinal dynamics between procedural justice and interpersonal helping in organizational teams. Journal of Business and Psychology, 30(3), 513-528.

Singelis, T. M., Triandis, H. C., Bhawuk, D. P. ve Gelfand, M. J. (1995). Horizontal and vertical dimensions of individualism and collectivism: A theoretical and measurement refinement. Cross-Cultural Research, 29(3), 240-275.

Spector, P. E. ve Fox, S. (2002). An emotion-centered model of voluntary work behavior: Some parallels between counterproductive work behavior and organizational citizenship behavior. Human Resource Management Review, 12(2), 269-292.

Stone, M. (1974). Cross-validatory choice and assessment of statistical predictions. Journal of the Royal Statistical Society. Series B (Methodological), 111-147.

Sugawara, I. ve Huo, Y. J. (1994). Disputes in Japan: A cross-cultural test of the procedural justice model. Social Justice Research, 7(2), 129-144.

Sung, S. Y., Choi, J. N. ve Kang, S. C. (2017). Incentive pay and firm performance: Moderating roles of procedural justice climate and environmental turbulence. Human Resource Management, 56(2), 287-305.

Tabassi, A. A., Roufechaei, K. M., Bakar, A. H. A. ve Yusof, N. A. (2017). Linking team condition and team performance: A transformational leadership approach. Project Management Journal, 48(2), 22-38.

Takano, Y. ve Osaka, E. (1999). An unsupported common view: Comparing Japan and the US on individualism/collectivism. Asian Journal of Social Psychology, 2(3), 311-341.

Taras, V., Kirkman, B. L. ve Steel, P. (2010). Examining the impact of culture's consequences: A three-decade, multilevel, meta-analytic review of Hofstede's cultural value dimensions. Journal of Applied Psychology, 95(3), 405.

Tenenhaus, M., Vinzi, V. E., Chatelin, Y. M. ve Lauro, C. (2005). PLS path modeling. Computational Statistics \& Data Analysis, 48(1), 159-205.

Thibaut, J. W. ve Walker, L. (1975). Procedural justice: A psychological analysis. L. Erlbaum Associates.

Triandis, H. C. (1989). The self and social behavior in differing cultural contexts. Psychological review, 96(3), 506-520.

Triandis, H. C. (1990) Cross-cultural studies of individualism and collectivism. Berman, J. J. (Ed.), Cross-cultural perspectives: Nebraska symposium on motivation içinde (41-133), NE: University of Nebraska Press.

Triandis, H. C. (1995). Individualism \& collectivism. Westview press, Boulder, CO.

Triandis, H. C., Bontempo, R., Villareal, M. J., Asai, M. ve Lucca, N. (1988). Individualism and collectivism: Cross-cultural perspectives on self-ingroup relationships. Journal of Personality and Social Psychology, 54(2), 323.

Triandis, H. C. ve Bhawuk, D. P. (1997). Culture theory and the meaning of relatedness. Earley, P.C. ve Erez, M. (Ed.), New perspectives on international industrial/organizational psychology içinde (1352), New York, NY; The New Lexington Free Press.

Triandis, H. C., Leung, K., Villareal, M. J. ve Clack, F. I. (1985). Allocentric versus idiocentric tendencies: Convergent and discriminant validation. Journal of Research in Personality, 19(4), 395-415.

Tse, H. H., Lam, C. K., Gu, J. ve Lin, X. S. (2018). Examining the interpersonal process and consequence of leader-member exchange comparison: The role of procedural justice climate. Journal of Organizational Behavior, 39(8), 922-940. 
Tyler, T. R. ve Blader, S. L. (2003). The group engagement model: Procedural justice, social identity, and cooperative behavior. Personality and Social Psychology Review, 7(4), 349-361.

Tyler, T., Degoey, P. ve Smith, H. (1996). Understanding why the justice of group procedures matters: A test of the psychological dynamics of the group-value model. Journal of Personality and Social Psychology, 70(5), 913.

Van Der Vegt, G. S., Van De Vliert, E. ve Oosterhof, A. (2003). Informational dissimilarity and organizational citizenship behavior: The role of intrateam interdependence and team identification. Academy of Management Journal, 46(6), 715-727.

Van Dyne, L., Vandewalle, D., Kostova, T., Latham, M. E. ve Cummings, L. L. (2000). Collectivism, propensity to trust and self-esteem as predictors of organizational citizenship in a non-work setting. Journal of Organizational Behavior, 21(1), 3-23.

York, R. (2012). Residualization is not the answer: Rethinking how to address multicollinearity. Social Science Research, 41(6), 1379-1386.

Wagner, J. A. (1995). Studies of individualism-collectivism: Effects on cooperation in groups. Academy of Management Journal, 38(1), 152-173.

Wagner, J. A., Humphrey, S. E., Meyer, C. J. ve Hollenbeck, J. R. (2012). Individualism-collectivism and team member performance: Another look. Journal of Organizational Behavior, 33(7), 946-963.

Wagner, J.A. ve Moch, M.K. (1986). Individualism-collectivism: Concept and measure. Group \& Organization Studies, 11(3), 280-304.

Walumbwa, F. O., Hartnell, C. A., ve Misati, E. (2017). Does ethical leadership enhance group learning behavior? Examining the mediating influence of group ethical conduct, justice climate, and peer justice. Journal of Business Research, 72, 14-23.

Walumbwa, F. O., Hartnell, C. A. ve Oke, A. (2010). Servant leadership, procedural justice climate, service climate, employee attitudes, and organizational citizenship behavior: A cross-level investigation. Journal of Applied Psychology, 95(3), 517.

Walumbwa, F. O., Wu, C. ve Orwa, B. (2008). Contingent reward transactional leadership, work attitudes, and organizational citizenship behavior: The role of procedural justice climate perceptions and strength. The Leadership Quarterly, 19(3), 251265.

Watson, W. E., Johnson, L. ve Merritt, D. (1998). Team orientation, self-orientation, and diversity in task groups: Their connection to team performance over time. Group \& Organization Management, 23(2), 161-188.
Welbourne, T. M., Johnson, D. E. ve Erez, A. (1998). The role-based performance scale: Validity analysis of a theory-based measure. Academy of Management Journal, 41(5), 540-555.

Wetzels, M., Odekerken-Schröder, G. ve Van Oppen, C. (2009). Using PLS path modeling for assessing hierarchical construct models: Guidelines and empirical illustration. MIS Quarterly, 33(1), 177-195.

Wong, K. K. K. (2013). Partial least squares structural equation modeling (PLS-SEM) techniques using SmartPLS. Marketing Bulletin, 24(1), 1-32.

Wong, K. K. K. (2016). Mediation analysis, categorical moderation analysis, and higher-order constructs modeling in Partial Least Squares Structural Equation Modeling (PLS-SEM): A B2B example using SmartPLS. Marketing Bulletin, 26.

Wood, M. O., Noseworthy, T. J. ve Colwell, S. R. (2013). If you can't see the forest for the trees, you might just cut down the forest: the perils of forced choice on "seemingly" unethical decision-making. Journal of Business Ethics, 118(3), 515-527. 


\section{Summary \\ The Effect of Team Collectivism on Performance and Citizenship Behavior: The Mediating Role of Peer Procedural Justice}

\author{
Arzu Sert Özen \\ Gebze Technical University \\ "If you want to go fast, go alone. \\ If you want to go far, go together" \\ - African Proverb.
}

Teams consist of two or more individuals who interact or coordinate with each other to achieve a common goal (Baker \& Salas, 1997). Teams, which have various positive effects on organizational outcomes, have gained ground in organizations in today's world. However, teamwork is a complicated issue, and organizations need to develop team-based strategies in order to achieve organizational goals (Gundlach, Zivnuska, \& Stoner, 2006).

Team collectivism refers to the shared perception of the members within the same team on how important common interests and welfare are compared to the individual interests, and how important the concepts of cohesion and collaboration are as team values (Colquitt, Noe, \& Jackson, 2002; Lai, Lam, \& Lam, 2013). Though various studies have shown that team collectivism has an effect on team member behavior, there are very few studies (e.g., Bell, 2007; Colquitt et al., 2002; Dayan \& Colak, 2008) that examined collectivism as a team-level variable. In the previous studies, it has been shown that team collectivism has an impact on procedural justice climate (Colquitt et al., 2002; Dayan \& Colak, 2008). However, to our knowledge, a study on the effect of team collectivism on peer procedural justice has not been conducted yet.

Cropanzano, Li, and Benson (2011) conducted the first study related to peer procedural justice, and this concept refers to the shared perception of justice regarding how fairly the team members treat one another in the decision-making process. Though it has been determined that procedural justice, which has been evaluated at the team level, has a positive relationship with team task performance and team citizenship behavior (e.g., Cropanzano et al., 2011), the potential factors which may affect such relationships have not been examined yet.

\author{
Meral Elçi \\ Gebze Technical University
}

Team task performance, which refers to the degree to which a team fulfills its objectives or tasks (Bell, 2007), is the most important indicator of a team's success. Team members need to fulfill their tasks in cooperation through cognitive, verbal, and behavioral activities to show successful performance (Marks, Mathieu, $\&$ Zaccaro, 2001). One of the effective elements in the cooperation of individuals with one another in the team context is collectivism (Wagner, 1995). In the previous studies conducted at the team level, it has been found that team collectivism had a positive effect on team effectiveness (Kirkman \& Shapiro, 2001) and team task performance through team collaboration (Eby \& Dobbins, 1997). Furthermore, a meta-analysis study at the team level conducted by Bell (2007) showed that team collectivism had a positive effect on team task performance.

Team citizenship behavior refers to team members' shared perceptions on the behaviors performed within the team such as voluntarily helping, sharing work load, participating in extra duties for the team success, and such, provides an empirical guide on how to behave in the future (Cropanzano et. al., 2011; Ehrhart, 2004). Team citizenship behavior is a concept considered different from the concept of organizational citizenship behavior at the individual level (toward organization or coworkers) because it regulates social interaction and affects social identity (Ehrhart, 2004; Ehrhart, Bliese, \& Thomas, 2006). In a study conducted at the individual level of analysis, Jackson, Colquitt, Wesson, and Zapata-Phelon (2006) found that psychological collectivism had a positive effect on team members' citizenship behaviors. In the same vein, the research conducted by Finkelstein $(2012,2014)$ demonstrated that collectivism had a positive effect on organizational citizenship behavior. However, to our knowledge, there is no study that examined the effects of collectivism as a team level construct on team citizenship behavior.

Address for Correspondence: PhD Candidate, Arzu Sert Özen, Gebze Technical University, Faculty of Business Administration, 41400, Gebze/Kocaeli.

E-mail: arzusertt@gmail.com 
As stated in the literature review, there are very few studies conducted at the team level on the variables of concern, and new studies are needed. Therefore, (a) the effects of team collectivism on peer procedural justice, team task performance, and team citizenship behavior, and (b) the mediator role of peer procedural justice in the relationship between team task performance and team citizenship behavior will be examined in this study. Thus, based on the literature review, we propose hypotheses as follows:

Hypothesis 1: Team collectivism would be positively related to peer procedural justice.

Hypothesis 2: Team collectivism would be positively related to team citizenship behavior.

Hypothesis 3: Team collectivism would be positively related to team task performance.

Hypothesis 4: Peer procedural justice would be positively related to team task performance.

Hypothesis 5: Peer procedural justice would be positively related to team citizenship behavior.

Hypothesis 6: Peer procedural justice would mediate team collectivism and team citizenship behavior relationship.

Hypothesis 7: Peer procedural justice would mediate team collectivism and team task performance relationship.

\section{Method}

\section{Sample and Data Collection}

The sample of this study consisted of 560 team members who worked in 93 teams. Participants, who worked in production and service teams took the survey. The sample comprised $36 \%$ female and $64 \%$ male participants. The average age of the team members was 32.7 years $(S D=8.16)$, and the average tenure was 3.3 years $(S D=3.26)$. Forty percent of the teams were composed of seven to ten individuals; $24 \%$ were composed of more than ten individuals; $19 \%$ were composed of two to four individuals; and $17 \%$ were composed of five to six individuals $(S D=.50)$. Additionally, $89 \%$ of participants had an undergraduate degree, and $11 \%$ had a post-graduate degree.

\section{Measures}

Team members responded to the questionnaires below with a 5-point Likert scale ranging from 1 (strongly disagree) to 5 (strongly agree).

Peer Procedural Justice. Peer procedural justice was measured using a 5-item scale developed by Li and Cropanzano (2009) based on the criteria proposed by Leventhal (1976) (Sample item: "We can express our emotions and thoughts about the decision-making pro- cess in our team."). The Cronbach's alpha was found to be .91 , and the test-retest reliability was $.96(p=.01)$.

Team Collectivism. Team collectivism was measured with a 6-item scale developed by Wagner (1995) (Sample item: "Individuals in the team should be disposed to make self-sacrifice for the good of their team."). For team collectivism, the average of the individual responses of team members was used (Colquitt et al., 2002). In this study, the Cronbach's alpha was found to be .87 , and the test-retest reliability was $.97(p=.01)$.

Team Task Performance. Team task performance was measured using a 9-item scale developed by Goodman and Svyantek (1999). Team task performance was evaluated by team supervisors' responses for their team members at the team level. High scores achieved by the teams show that team task performance was high (Sample item: "Team members achieve the objectives of the job."). The Cronbach's alpha was found to be .86 .

Team Citizenship Behavior. Based on the previous studies (Cropanzano et al., 2011; Van der Vegt, Van de Vliert, \& Oosterhof, 2003), we focused on helpfulness and faithfulness regarding the social team process of the organizational citizenship behavior in order to measure team citizenship behavior. Helping behavior was measured via a 4-item scale (Sample item: "Team members help the others who have a heavy workload"), and loyalty behavior was measured via a 3-item scale (Sample item: "Team members never avoid extra duties and responsibilities for the tasks"), both of which were adapted to team level by Cropanzano et al. (2011) based on the research by Van der Vegt et al. (2003). For team citizenship behavior, the average of team members' responses was used. In this study, the test-retest reliabilities for helping and loyalty behavior were found, respectively, as .93 and $.98(p=.01)$. As the discriminant validity of the two subdimensions could not be established in this scale, all items were collected in a single dimension. In this study, the Cronbach's alpha was found as .95.

\section{Procedure}

In this study, the structural model was tested via structural equation model (SEM) using SmartPLS (v. 3.2.7) software by running the bootstrap resampling method (with 1000 resamples).

\section{Results}

$\mathrm{H}_{1}$ predicted that team collectivism would be positively related to peer procedural justice. The research findings indicated that team collectivism had a statistically positive effect on peer procedural justice $(\beta=.50$, $t=6.93, p<.001$ ); therefore, $\mathrm{H}_{1}$ was supported. $\mathrm{H}_{2}$ predicted that team collectivism would be positively related 
to team citizenship behavior. The results suggested that team collectivism had a statistically positive effect on team citizenship behavior $(\beta=.25, t=3.11, p=.002)$; thus, $\mathrm{H}_{2}$ was supported. Furthermore, $\mathrm{H}_{3}$ predicted that team collectivism would be positively related to team task performance. As predicted, the results demonstrated that team collectivism predicted team task performance positively $(\beta=.29, t=2.69, p=.009)$; therefore, $\mathrm{H}_{3}$ was supported. $\mathrm{H}_{4}$ proposed that peer procedural justice would be positively related to team task performance. As proposed, the findings suggested that peer procedural justice had a statistically positive effect on team task performance $(\beta=.34, t=3.02, p=.003)$; hence, $\mathrm{H}_{4}$ was supported. Additionally, $\mathrm{H}_{5}$ predicted that peer procedural justice would be positively related to team citizenship behavior. It was found that peer procedural justice had a statistically positive effect on team citizenship behavior $(\beta=.63, t=8.72, p<.001)$; therefore, $\mathrm{H}_{5}$ was supported.

Additionally, the mediator effect of peer procedural justice was examined in this research. The indirect effect of team collectivism on team task performance and team citizenship behavior via peer procedural justice was found statistically significant. Furthermore, there was a significant and linear relationship between team collectivism and team task performance, and the path coefficient decreased from $\beta=.46(p<.001)$ to $\beta$ $=.29(p=0.009)$ after the inclusion of the mediator variable in the model. However, including this mediating effect increased $R^{2}$ from .21 to .29 . The path coefficient decreased from $\beta=.57(p<.001)$ to $\beta=.25(p=0.002)$ after introducing peer procedural justice as mediator of the path between team collectivism and team citizenship behavior. However, including the mediating effect increased $R^{2}$ from .32 to .62 . Therefore, it can be said that peer procedural justice had a partial mediator role. In addition, the total effect and the variance accounted for (VAF) values were used to examine the magnitude of mediation (Wong, 2016). The total effect is found with the accumulation of the direct effect and indirect effect. The total effect in $\mathrm{H}_{6}$ was $.25+.31=.56$, and the total effect in $\mathrm{H}_{7}$ was $.29+.17=.46$. The VAF value was calculated as the indirect effect divided by the total effect. The threshold value for the VAF value is .20 and values below .20 indicate that there is no mediating effect. The values between .20 and .80 indicate partial mediating effect, and the values which are .80 and above indicate full mediating effect (Hair, Hult, Ringle, \& Sarstedt, 2013). The VAF value for $\mathrm{H}_{6}=.31 / .56=.55$ and for $\mathrm{H}_{7}=.17$ $/ .46=.37$. Fifty-five percent of the effect of team collectivism on team citizenship behavior was explained by the mediating variable, peer procedural justice; and the magnitude of the mediation was partial. Thus, $\mathrm{H}_{6}$ was partially supported. Thirty-seven percent of the ef- fect of team collectivism on team task performance was explained by the mediating variable, peer procedural justice; and the magnitude of the mediation was partial. Thus, $\mathrm{H}_{7}$ was partially supported.

\section{Discussion}

The aim of this study was to investigate the predictive effect of team collectivism on team citizenship behavior and team task performance, and also to test whether peer procedural justice had a mediating role in the relationships of team collectivism with team task performance and team citizenship behavior. The findings indicated that team collectivism had a positive effect on peer procedural justice, team citizenship behavior, and team task performance, and that peer procedural justice had a partial mediator role in the relationships of team collectivism with team citizenship behavior and team task performance.

The results of this research are consistent with the literature on collectivism. In previous studies (e.g., Colquitt et al., 2002; Dayan \& Colak, 2008), it was found that team collectivism had a positive relationship with procedural justice climate. In this study, it was found that collectivism at the team level had a positive relationship with the perceptions of peer procedural justice. Additionally, the findings are similar to those of previous studies conducted at the individual level of analysis which showed that collectivism had positive effects on organizational citizenship behavior (e.g., Finkelstein, 2012, 2014; Jackson et al., 2006; Van Dyne, Vandewalle, Kostova, Latham, \& Cummings, 2000) and team task performance (Bell, 2007; Eby \& Dobbins, 1997). Additionally, it has been found that peer procedural justice at the team level affected team task performance and team citizenship behavior (Cropanzano et al., 2011).

The current study has several theoretical implications. First, to our knowledge, there has been no study that examined the effect of team collectivism on peer procedural justice in the field so far. Secondly, although the effect of collectivism on team citizenship behavior has been tested, none of the scholars have tested the effect of collectivism at the team level. As Ehrhart (2004) stated that team citizenship behavior could not be fully explained by the antecedents of organizational citizenship behavior at the individual level, collectivism has been considered as a variable at the team level in this study. As a result, this study indicated that team collectivism had a significant positive effect on team citizenship behavior. Finally, by examining a mediational model, it was demonstrated that the effect of team collectivism on team citizenship behavior and team task performance seems to be partially mediated through peer procedural justice. 
The current study has various contributions to practice. Firstly, it has been found that team collectivism had a positive effect on team performance. Collectivists show better performance and become more successful in teamwork compared to individualists. On the other hand, though it is highly difficult to determine how the individualistic team members, who value their own interests above the team interests, work effectively with other team members, individuals can be turned into successful team members with careful planning and foresight. Unifying the team objective and the individual objective and rewarding individual contributions can provide an opportunity to fulfill the teamwork and prevent possible group productivity losses. In this regard, it has been thought that it can be beneficial for managers to consider individuals' compliance with the team values in personnel selection and make plans accordingly. Thus, this can contribute to achieving positive outcomes, such as decreased intention to leave and increased work satisfaction, performance, and team cohesion.

Team collectivism is a concept that positively affects perceptions of procedural justice within the team. When team collectivism is low, the perception of injustice that may occur within the team increases the turnover rates and decreases the performance. In such cases, managers should consider that it is important to support peer procedural justice in order to increase the cohesion of the team. In this regard, teaching the employees to be fair is one of the methods to be followed. Thus, the employees' tendency to act negatively can be decreased, and they might help the other individuals in the team and work efficiently (Greenberg, 2005).

One of the main limitations of this study is that it is a cross-sectional study. A longitudinal study is required to test causal relationships more precisely (Colquitt et al., 2002; Ehrhart, 2004; Molina, Moliner, Martínez-Tur, Cropanzano, \& Peiro, 2015). Another limitation of this study is the evaluation of team task performance by a single supervisor. For future studies, it is recommended that two supervisors' independent evaluations are obtained for team performance so that the inter-rater reliability can be measured (Cropanzano et al., 2011). Lastly, evaluation of the cross-level effects of variables at the team level (e.g., peer justice) on variables at the individual level (e.g., the individual's intention to leave or job-related stress) will offer a more sophisticated analysis and contribution to the literature. 